\title{
The synthesis of 16-dehydropregnenolone acetate (DPA) from potato glycoalkaloids
}

\author{
Patrick J.E. Vronen ${ }^{a}$, Nadeshda Koval ${ }^{b}$, and Aede de Groot ${ }^{\mathrm{a} *}$ \\ ${ }^{a}$ Laboratory of Organic Chemistry, Wageningen University, Dreijenplein 8, \\ 6703 HB Wageningen, The Netherlands, and \\ ${ }^{b}$ Institute of Bioorganic Chemistry, National Academy of Sciences of Belarus, \\ Kuprevich str. 5/2, 220141, Minsk, Belarus \\ E-mail: Aede.deGroot@wur.nl
}

Dedicated to Professor Binne Zwanenburg on his $70^{\text {th }}$ birthday

(received 18 Sep 03; dedicated 18 Nov 03; published on the web 21 Nov 03)

\begin{abstract}
The use of solanidine as starting material for the synthesis of steroid hormones was strongly stimulated by the possibility to isolate large amounts (ton scale) of potato glycoalkaloids from a waste stream of the potato starch production. A procedure is available to isolate these glycoalkaloids from the potato protein fraction and after hydrolysis solanidine is set free and can be made available as alternative for diosgenine as starting material for the production of dehydropregnenolon acetate (DPA). The conversion of solanidine to DPA was first tried by reinvestigation of several known methods like oxidation with $\mathrm{Hg}(\mathrm{OAc})_{2}$, the Cope reaction and the Polonovski reaction but none of these approaches were successful. The best option was to open the E,F-ring system using the Von Braun reaction. Besides the desired major E-ring opened compound also the minor F-ring opened compound was isolated. Alternatives for the hazardous Von Braun reagent $\mathrm{BrCN}$ were investigated but not found. Further degradation using the Hofmann reaction was successful in a $\Delta^{16}$ derivative, which led to the desired triene intermediate.

Finally DPA could be obtained starting from solanidine in 9 reaction steps in $30 \%$ overall yield using the known conversion to spirosolane compounds followed by conversion to DPA. Extensive research has been performed on finding shortcuts in this route but despite all our efforts, further shortening of the route from 3-acetoxysolanidine via tomatidenol to DPA could not be accomplished.
\end{abstract}

Keywords: Solanidine, dehydropregnenolon acetate, Von Braun reaction, Hofmann degradation 


\section{Introduction}

Since the first structure elucidation of solanidine (1) about 70 years ago, research has been carried out to convert this aglycon to an intermediate for the synthesis of steroids. Renewed interest in this conversion was stimulated by the possibility to isolate large amounts (ton scale) of potato glycoalkaloids from a waste stream of the potato starch production. During the starch refining process the proteins together with the glycoalkaloids are separated from the starch. This protein fraction is then subjected to a number of refining steps in which the proteins are separated from the glycoalkaloids. The glycoalkaloids together with free amino acids, peptides and minerals end up in the so-called protamylasse fraction. The amount of glycoalkaloids present in this fraction varies from 200-2000 ppm dependent on the potatoes processed per campaign. Potato glycoalkaloids consist for more than $95 \%$ of $\alpha$-chaconine and $\alpha$-solanine, which both have the steroid-like solanidine (1) as aglycon, thus a large potential of starting material may become available for conversion to steroid hormones.

During the last 50 years diosgenine is used as the main starting material in the industrial synthesis of progestagens, androgens, estrogens, norsteroids, and a diuretic spironolactone. Uncertain external factors have often influenced the guaranteed supply of diosgenine and in the course of time many alternatives have been investigated. These alternatives should have in common that they can be implemented in existing production facilities for economic and pharmaceutical reasons. Solanidine (1) could be such an alternative on condition that it can be converted in an industrially attractive way to DPA (6), which is a key intermediate in the industrial syntheses of progesterone and cortisone derivatives. We here like to report on our results in this field.

\section{Results and Discussion}

\section{Isolation and hydrolysis of potato glycoalkaloids}

To obtain the starting material for our research, an improved simple and effective method has been developed for the isolation of the potato glycoalkaloids, $\alpha$-chaconine and $\alpha$-solanine, from the spray dried protamylasse fraction, which was obtained from AVEBE ${ }^{1}$. When this crude fraction was directly subjected to hydrolysis a complex product mixture was formed. Therefore a modified method of Friedman et al. ${ }^{2}$ was used for the extraction of the potato glycoalkaloids from the protamylasse fraction. A crude mixture of $\alpha$-chaconine and $\alpha$-solanine was obtained by using aqueous ethanol for this extraction, and recrystallization from ethanol gave a clean mixture of both glycoalkaloids. In this way $221.1 \mathrm{~g}$ of spray-dried protamylasse yielded $10.8 \mathrm{~g}$ of glycoalkaloids, which is $85 \%$ yield based on a $5.7 \%$ glycoalkaloid content in the spray-dried protamylasse as determined by HPLC. Chemical hydrolysis was performed with acid and 
solanidine (1) was isolated from the acidic ethanol in an almost quantitative yield after precipitation with $\mathrm{NH}_{4} \mathrm{OH}$.

Because both the isolation and hydrolysis of the glycoalkaloids can be performed on a large scale, attempts were made to combine both procedures. Since the protamylasse fraction has a $\mathrm{pH}$ of 5-6 it could be dissolved in water without addition of acid. After the aqueous solution was made basic with $\mathrm{NH}_{4} \mathrm{OH}$ and stored overnight at $4^{\circ} \mathrm{C}$, the slurry was centrifuged and the supernatant discarded. The pellet was again directly subjected to hydrolysis but also in this case a complex product mixture was formed, and extraction with ethanol proved to be necessary prior to hydrolysis. Thus the pellets were transferred to a Soxhlett apparatus and extracted with ethanol for 24 hours. After concentration of the extract, a crude glycoalkaloid fraction was obtained. This fraction was hydrolyzed in acidic ethanol for 2.5 hours, and the alkaloids were precipitated with $\mathrm{NH}_{4} \mathrm{OH}$. The crude precipitate was filtered and recrystalized from ethanol to give pure solanidine (1). The hydrolysis of the glycoalkaloids is accompanied by the formation of solanidiene in $9 \%$ yield, but lowering the amount of acid in the hydrolysis step from $2 \mathrm{M}$ to $1 \mathrm{M} \mathrm{HCl}$ in ethanol reduced the formation of solanidiene to a negligible amount.

\section{The conversion of solanidine to DPA}

The conversion of solanidine (1) to DPA (6) was first tried by the recently published method using $\mathrm{Hg}(\mathrm{OAc})_{2}$ as oxidation reagent. ${ }^{3}$ Electrochemical ${ }^{4,5}$ oxidations of solanidanes have shown that the $\Delta^{22(\mathrm{~N})}$-iminium salt is exclusively formed in acetone, while the $\Delta^{16(\mathrm{~N})}$-iminium salt is the sole product in $\mathrm{CH}_{2} \mathrm{Cl}_{2}$, in both cases pyridine is added as base. Chemical ${ }^{6,7}$ oxidation of solanidine with $\mathrm{Hg}(\mathrm{OAc})_{2}$ in acetone or $\mathrm{CH}_{2} \mathrm{Cl}_{2}$ showed the same preference in formation of the $\Delta^{16(\mathrm{~N})}$-iminium and $\Delta^{22(\mathrm{~N})}$-iminium salts.
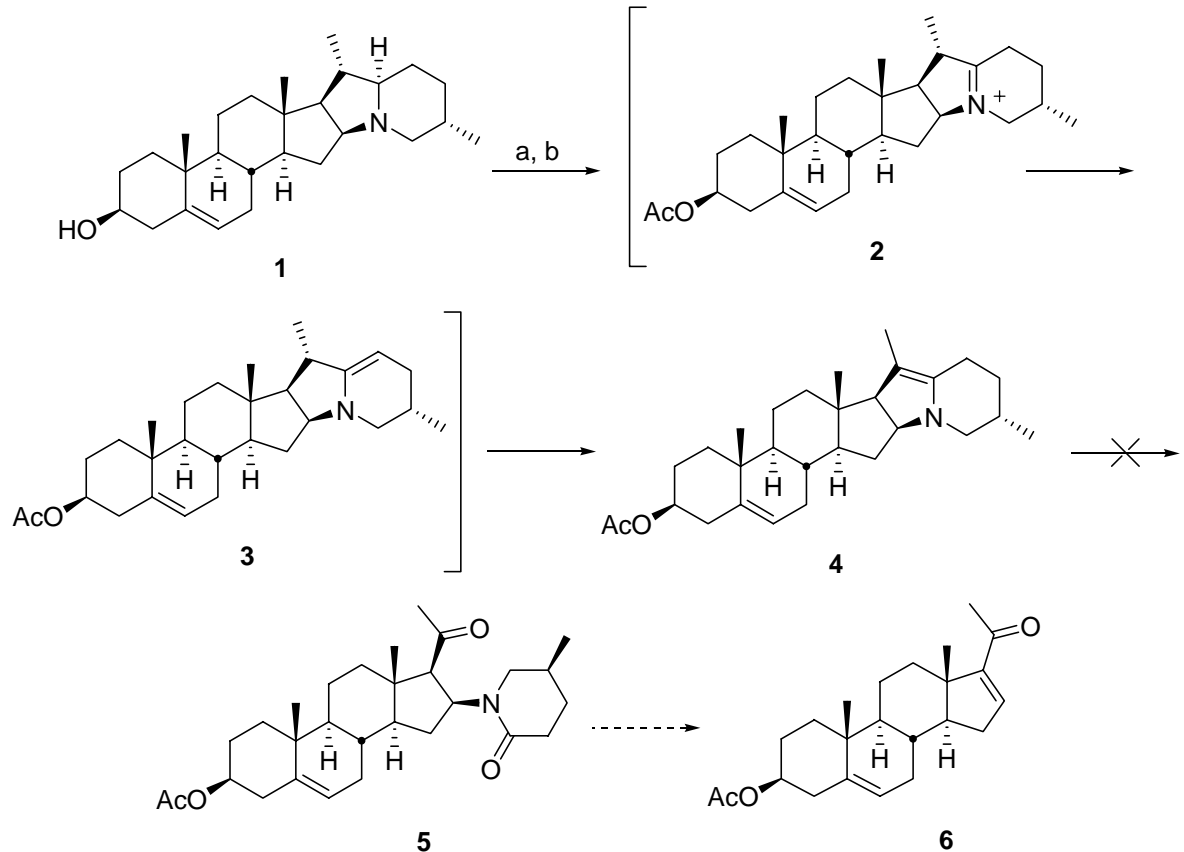

Scheme 1. a. $\mathrm{Ac}_{2} \mathrm{O}$, pyridine, $98 \%$. b. $\mathrm{Hg}(\mathrm{OAc})_{2}$, acetone, $97 \%$. 
In 1997 Gaši et al. $^{3}$ reported the conversion of solanidine (1) to DPA (6) via iminium ion 2 and the enamine intermediates 3 and 4 (Scheme 1). Enamine 4 is oxidized with $\mathrm{NaIO}_{4}, \mathrm{NaI}$, and $\mathrm{NaHCO}_{3}$ in a mixture of water and $t-\mathrm{BuOH}$ to ketolactam $\mathbf{5}$, and elimination of the lactam moiety in 5 gives DPA (6) in an overall yield of 28\%. Before reinvestigation of the degradation of solanidine (1), it was converted to its acetate prior to oxidation with $\mathrm{Hg}(\mathrm{OAc})_{2}$. Because the $\mathrm{Hg}(\mathrm{OAc})_{2}$ contained some acetic $\mathrm{acid}^{7}$, enamine 4 was directly formed in $90 \%$ yield, which made the separate isomerization step superfluous. However, oxidation of enamine $\mathbf{4}$ according to the procedure of Gaši et al. ${ }^{3}$ was unsuccessful in our hands and the starting material was recovered almost quantitatively. Many other oxidation reagents were tried (ozone, ${ }^{8} \mathrm{O}_{2} / \mathrm{CuCl}^{9}{ }^{9}$ $\mathrm{MnO}_{2}{ }^{10,11} \mathrm{KMnO}_{4}{ }^{12}{ }^{\mathrm{KMnO}} 4 / \mathrm{Al}_{2} \mathrm{O}_{3},{ }^{13} \mathrm{CrO}_{3} / \mathrm{HOAc},{ }^{14-16} \mathrm{CrO}_{3} /$ pyridine, ${ }^{17} \mathrm{H}_{2} \mathrm{O}_{2},{ }^{18} \mathrm{MMPP}^{19}$ ), but in all cases no oxidation product could be obtained. To rule out a possible involvement of the $\Delta^{5,6}$ double bond during the oxidation, ${ }^{20} 1$ was transformed into solanidan-4-en-3-one (7) by treatment of 1 with $\mathrm{Al}(\mathrm{i}-\mathrm{PrO})_{3}$ in toluene in the presence of cyclohexanone (Scheme 2). Oxidation of enone (7) with $\mathrm{Hg}(\mathrm{OAc})_{2}$ again showed the exclusive formation of the corresponding $\Delta^{20,22}$-enamine, which was subjected again to a range of oxidation reactions, ${ }^{3,8,10-}$ $16,18,19,21$ but all failed in our hands.

According to Gaši and co-workers ${ }^{3}$ the modest yield of the oxidation of enamine 4 was due to its instability. However, Mopac ${ }^{22} \mathrm{PM} 3$ calculations ${ }^{23,24}$ showed that enamine $4\left(\Delta \mathrm{H}_{\mathrm{f}}=-76.57\right.$ kcal) is more stable than enamine $\mathbf{3}\left(\Delta \mathrm{H}_{\mathrm{f}}=-68.86 \mathrm{kcal}\right)$. The energy difference is large enough to make isomerization during the oxidation reaction unlikely and the difficulties in the oxidation reaction can not only be imputed to the instability of enamine 4 . These calculations also show that enamine 4 is not really an enamine but more an isolated double bond and a separate amino group. The bond order of the $\mathrm{C}-\mathrm{N}$ bond is 1.03 , which indicates that there is nearly a single bond between $\mathrm{C} 22$ and $\mathrm{N}$. The $\Delta^{20,22}$ double bond forces the five membered E-ring to be completely flat, and as a consequence the D-ring is bent in such a way that C18 and the six membered ring shield its top and bottom side, respectively (Figure 1). The methyl group (C21) lies in the plane of the $\Delta^{20,22}$ double bond making it even more difficult to approach. In our opinion, steric hindrance is the main reason for the low reactivity of this $\Delta^{20,22}$ double bond.

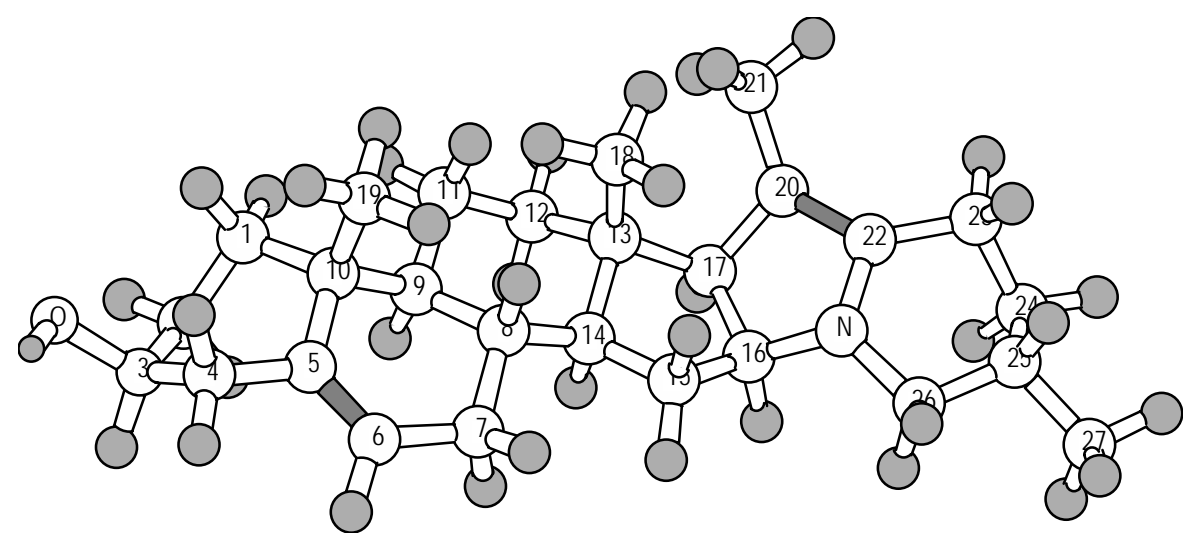

Figure 1. Enamine 4. 


\section{The Cope and Polonovski reactions}

In the second attempt to convert solanidine (1) to DPA (6) the Cope and Polonovski reactions were studied and to do so it was necessary to synthesize a solanidine $N$-oxide first. To avoid epoxidation problems solanidine (1) was converted to solanidi-4-en-3-one (7), which could be oxidized with MMPP to the corresponding solanidi-4-en-3-one $N$-oxide (8) in good yield (Scheme 2). It turned out that the Cope reaction did not give the desired results because a 5 membered planar transition state, necessary for the Cope reaction, is not possible in this molecule. In such cases deoxygenation, being a competitive process, takes over and indeed, solanidi-4-en-3-one (7) was recovered in all attempts.

The Polonovski reaction can be carried out with $\mathrm{Ac}_{2} \mathrm{O}$ or $\left(\mathrm{CF}_{3} \mathrm{CO}\right)_{2} \mathrm{O}$ under rather extreme conditions. With $\mathrm{Ac}_{2} \mathrm{O}$ no reaction was observed for solanidine $N$-oxide (8) or 3acetoxysolanidine $\mathrm{N}$-oxide (9). Treatment of $\mathbf{9}$ with $\left(\mathrm{CF}_{3} \mathrm{CO}\right)_{2} \mathrm{O}$ yielded compound $\mathbf{1 0}$ as the result of elimination, isomerization of iminium ion $\mathbf{2}$ and trifluoroacylation (Scheme 3). This is a new result, but no further attempts have been undertaken to convert compound 10 in DPA (6).

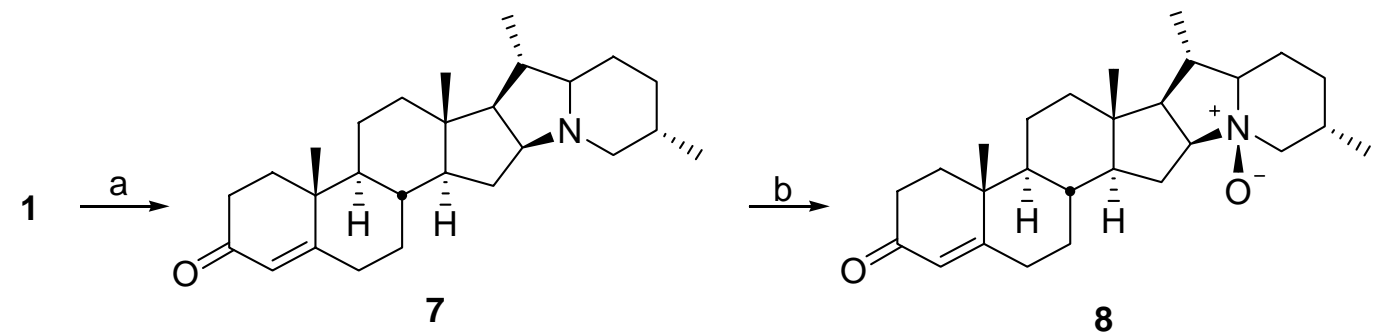

Scheme 2. a. $\mathrm{Al}(\mathrm{i}-\mathrm{PrO})_{3}$, toluene, cyclohexanone, $\Delta, 72 \%$. b. $\mathrm{MMPP}, \mathrm{CH}_{2} \mathrm{Cl}_{2}, \mathrm{H}_{2} \mathrm{O}, \mathrm{RT}, 12 \mathrm{~h}$, $53 \%$.

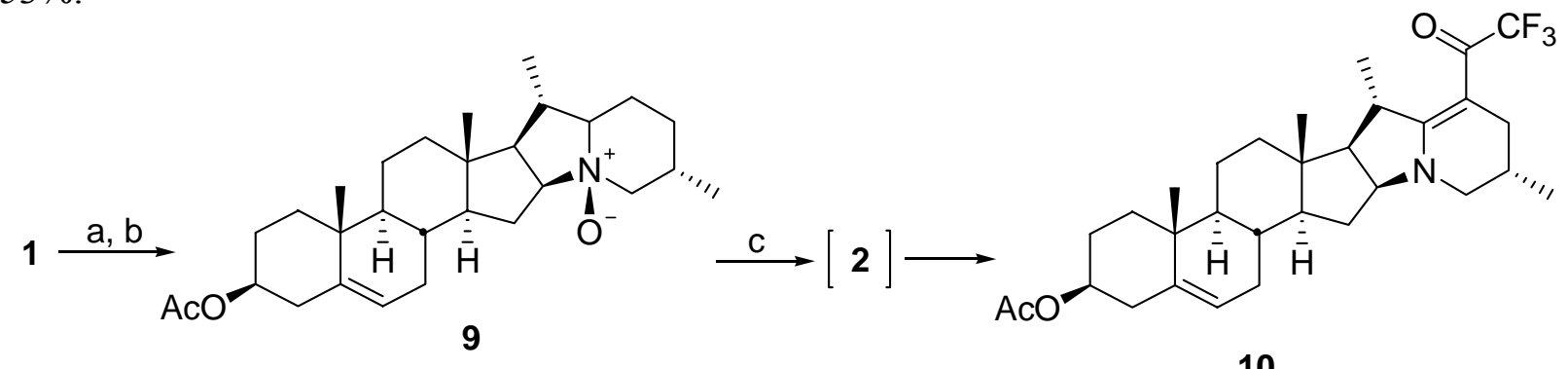

Scheme 3. a. $\mathrm{Ac}_{2} \mathrm{O}$, pyridine, $97 \%$. b. $m \mathrm{CPBA}, \mathrm{CH}_{2} \mathrm{Cl}_{2}, \mathrm{RT}, 2$ hours, $90 \%$. c. $\left(\mathrm{CF}_{3} \mathrm{CO}\right)_{2} \mathrm{O}$, THF, $t$-BuOK, $t$-BuOH, RT, 6 h, $41 \%$.

\section{The Von Braun reaction}

The third option was to open the E,F-ring system using the Von Braun reaction, which was performed on 3-acetoxysolanidine (11) according to the method of Beisler and Sato. ${ }^{25,26}$ Next to a $68 \%$ yield of 12, the F-ring opened side-product 13 was isolated in $10 \%$ yield, which must be the result of bromide attack at C26 (Scheme 4). Although not described in the literature, it is 
most likely that this product is always formed in the Von Braun reaction but it has never been mentioned before.

Because the use of $\mathrm{BrCN}$ in industry requires special safety measures, less toxic alternatives such as acetyl chloride, ${ }^{27,28}$ ethyl chloroformate, ${ }^{29-35}$ trichloroethyl chloroformate, ${ }^{36}$ benzoylchloride, ${ }^{37}$ and benzyl chloride ${ }^{38}$ have been investigated. Although these reagents give good results with common tertiary amines, no reaction was observed with 3-acetoxysolanidine (11). Other attempts with $\mathrm{Ac}_{2} \mathrm{O}$ and $\left(\mathrm{CF}_{3} \mathrm{CO}\right)_{2} \mathrm{O},{ }^{39}$ trichlorotriazine, chlorodimethoyxytriazine ${ }^{40-}$ ${ }^{42}$ and $\mathrm{TMSCl}, \mathrm{NaI}, \mathrm{Ac}_{2} \mathrm{O}^{43}$ were also unsuccessful.
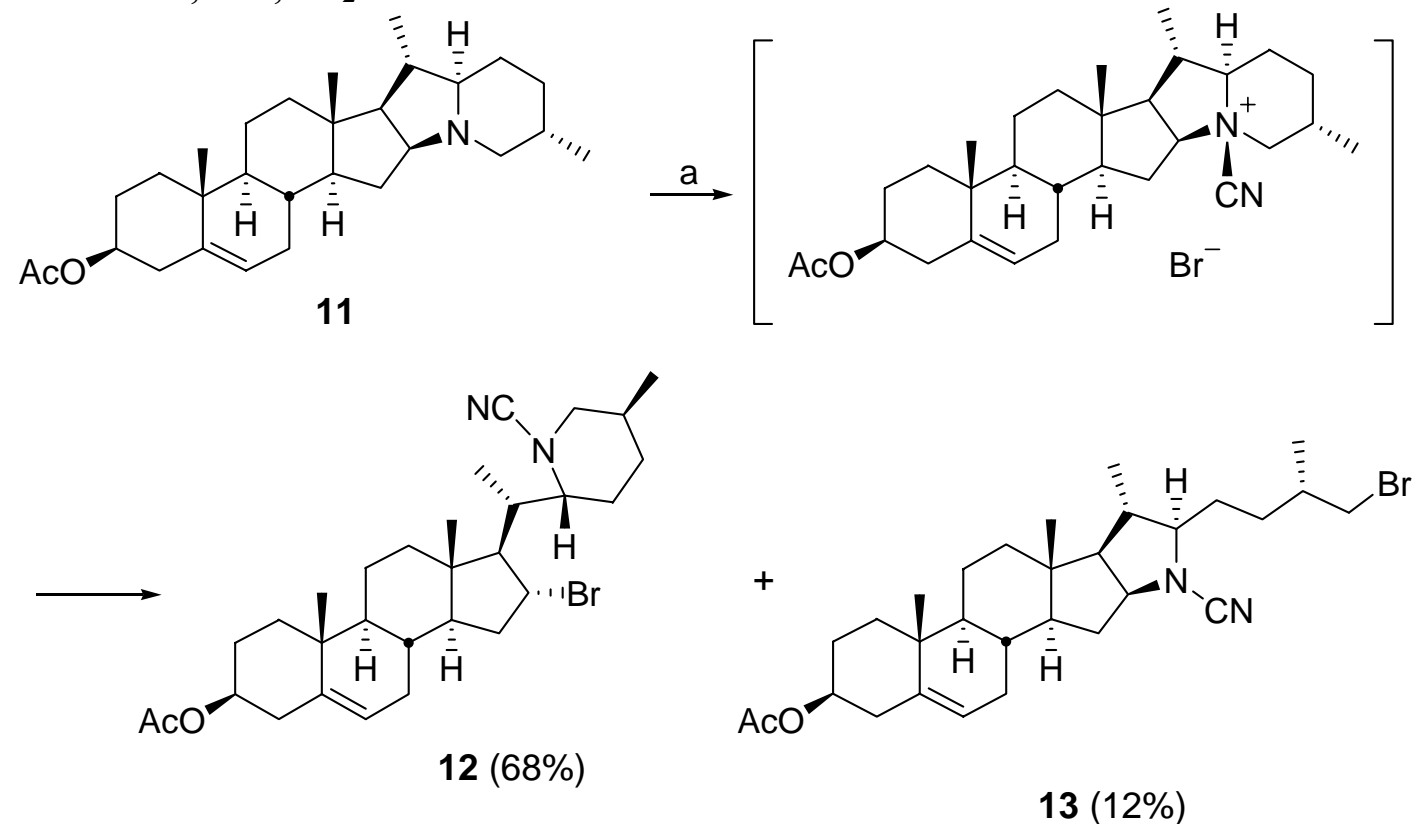

Scheme 4. a. $\mathrm{BrCN}, \mathrm{CHCl}_{3}, 24$ h.

The fact that ringopening can only be achieved with $\mathrm{BrCN}$ can be explained by the unique electronic and steric properties of this reagent. Besides, a striking difference between an $\mathrm{N}$-atom bearing a nitrile group, and an acylated $\mathrm{N}$-atom is the formal positive charge of the $\mathrm{N}$-atom as shown by MOPAC PM3 calculations. The $\mathrm{N}$-atom of the intermediate $N$-nitrilium ion possesses a formal charge of +0.75 while the $\mathrm{N}$-atom of the corresponding $\mathrm{N}$-acylium ion has a charge of only +0.38 . This makes the neighboring $\mathrm{C}$-atoms in the $N$-nitrilium ion much more susceptible to nucleophilic attack than in the $\mathrm{N}$-acylium ions.

Despite all attempts, $\mathrm{BrCN}$ remains the only reagent until now, capable to open the indolizidine ring system of 3-acetoxysolanidine (11). Although the objectives against large-scale industrial application of $\mathrm{BrCN}$ remain, the reaction itself gives a good yield of 12, which has possibilities for further transformation to DPA (6).

\section{The Hofmann degradation}

One of the possibilities for further transformation of the ringopened product $\mathbf{1 2}$ is the Hofmann degradation. To avoid disturbing side reactions under the basic reaction conditions, the bromide 
was removed, replaced by an acetate or eliminated. Treatment of $\mathbf{1 2}$ with $\mathrm{Bu}_{3} \mathrm{SnH}$ and $\mathrm{AIBN}$ in benzene at reflux temperature, gave $\mathbf{1 4}$ in $94 \%$ yield. Treatment of $\mathbf{1 2}$ with KOAc in DMF at $90^{\circ} \mathrm{C}$ gave the acetate 15 in $83 \%$ yield $^{26}$ and introduction of the $\Delta^{16,17}$ double bond was achieved by treatment of $\mathbf{1 2}$ with s-collidine to afford $\mathbf{1 6}$ in $98 \%$ yield. ${ }^{7}$ Direct methylation of these nitriles was unsuccessful as expected, so the nitrile was removed by reduction with Red-Al to give the corresponding secondary amines.

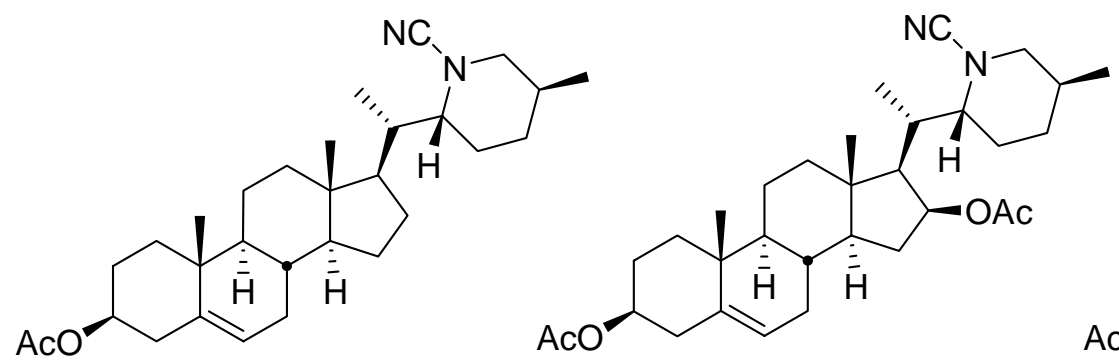

14
15

$\downarrow a, b$

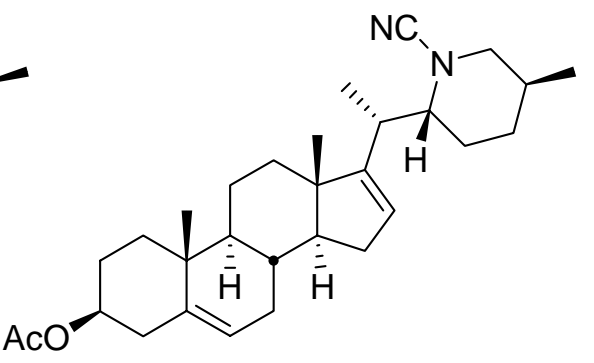

16

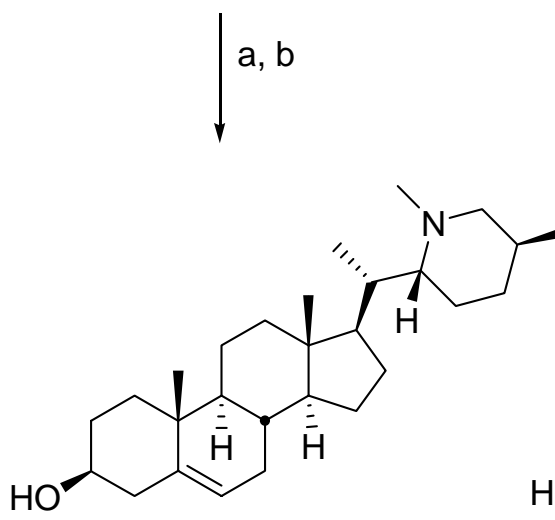

17

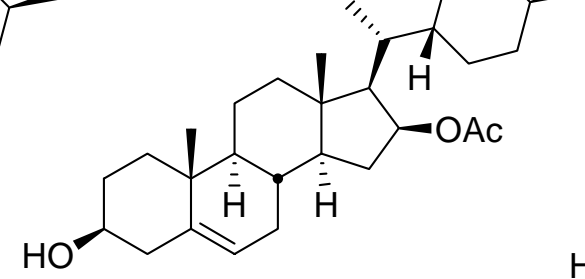

18

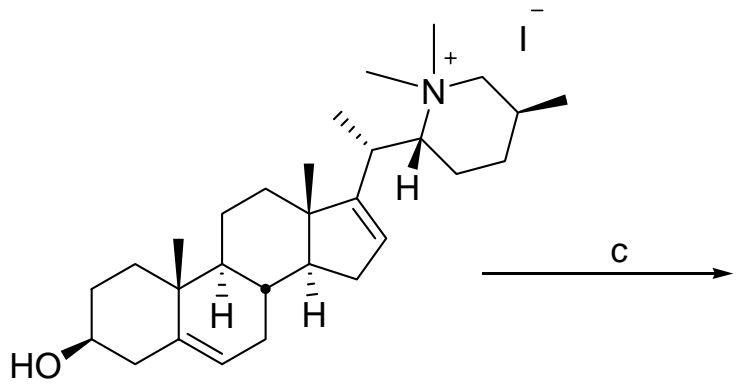

20

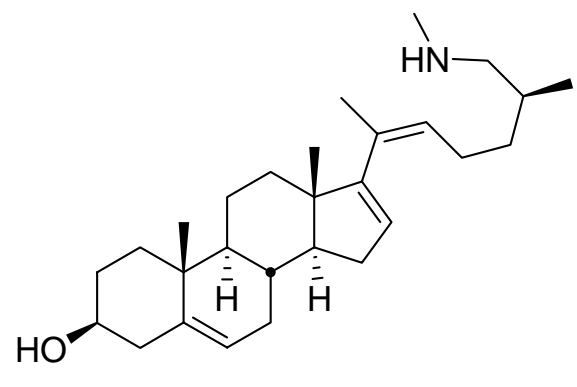

$21(32 \%)+19(26 \%)$

Scheme 5. a. Red-Al, toluene, $\Delta$. b. $\mathrm{Na}_{2} \mathrm{CO}_{3}$, MeI, then $\mathrm{KOH}, \mathrm{MeOH}, \tilde{\Delta}$ c. LDA, THF, $-78^{\circ} \mathrm{C}$, $32 \%(\mathbf{2 0}), 26 \%(\mathbf{1 9})$.

Methylation with $\mathrm{MeI}$ and $\mathrm{Na}_{2} \mathrm{CO}_{3}$ in water proceeded smoothly and gave the ammonium salts in high yields, which were subjected to treatment with base without further purification. This resulted in formation of the demethylated products $\mathbf{1 7}$ and $\mathbf{1 8}$ in $76 \%$ and $32 \%$ yield, 
respectively. Treatment of the unsaturated ammonium salt 20 with $\mathrm{KOH},{ }^{44} t-\mathrm{BuOK},{ }^{45,46}$ $\mathrm{NaOH},{ }^{47,48} \mathrm{NaOMe},{ }^{49}$ or $\mathrm{Et}_{3} \mathrm{~N}^{50}$ gave products which immediately decomposed during the isolation process. Only when $\mathbf{2 0}$ was treated with LDA the desired product 21 together with the $\mathrm{N}$-monomethylated product 19 could be isolated in $32 \%$ and $26 \%$ yield, respectively (Scheme 5). The formation of demethylated products can be explained by difficulties in the proton abstraction, which is necessary for ringopening. In these cases the competitive nucleophilic substitution resulting in demethylation is strongly favored over the Hofmann degradation. LDA is a small and strong enough base to abstract the proton from C20, but only in the case of $\mathbf{2 0}$ compound 21 was formed. The presence of the $\Delta^{16,17}$ double bond makes H20 to an allylic proton, which is more prone to abstraction. The further degradation of 21 to DPA (6) requires several protection and deprotection steps as shown by Maitra and Breslow, ${ }^{51}$ which are not very attractive for industrial application. Besides the use of several hazardous reagents is another reason to look for alternatives.

\section{The spirosolane routes}

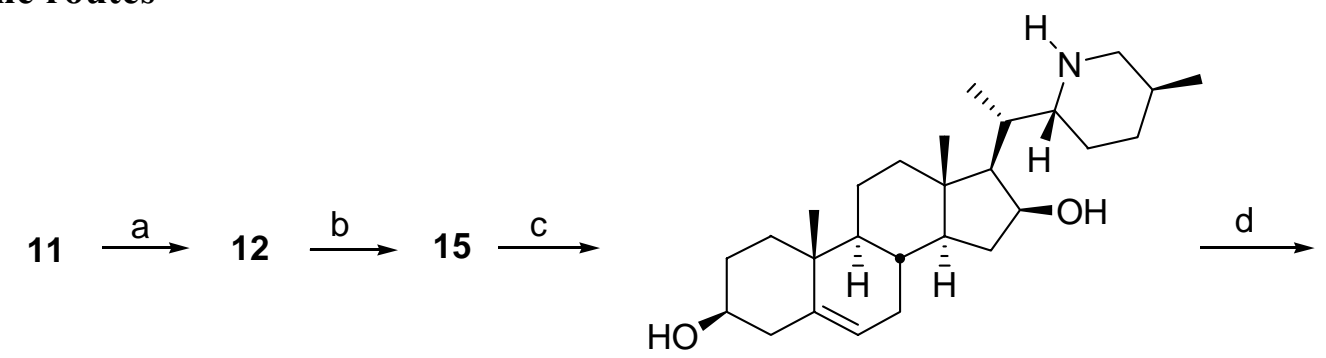

22

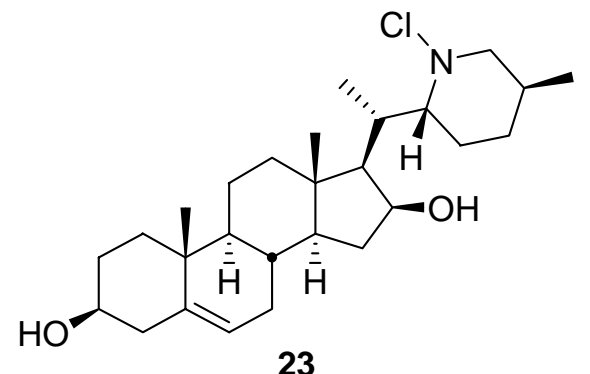

23

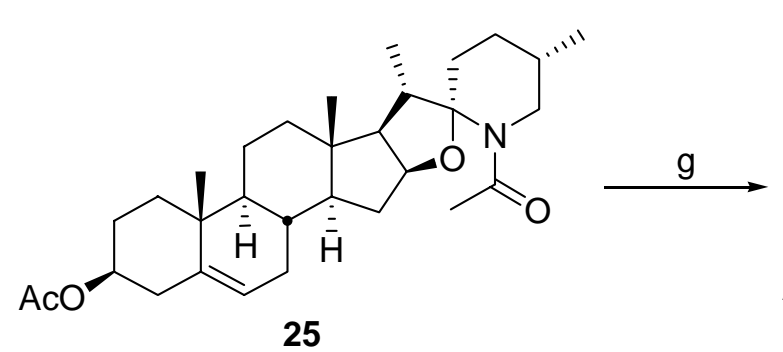

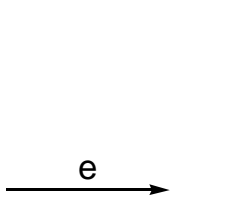

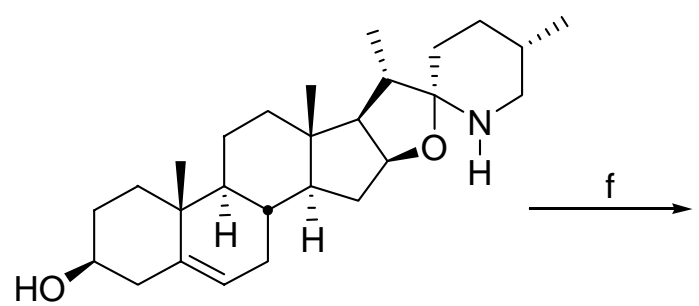

24

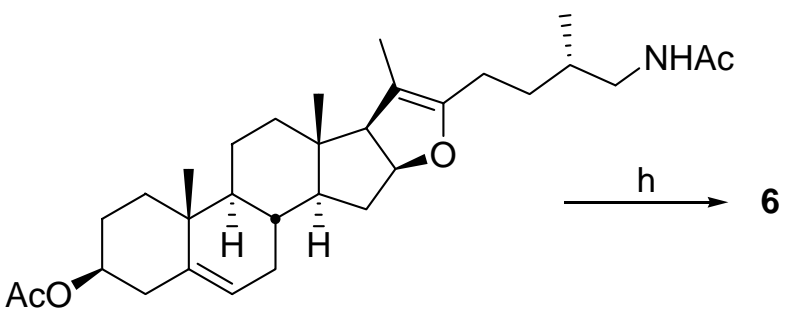

26

Scheme 6. a. $\mathrm{BrCN}, \mathrm{CHCl}_{3}, \Delta, 24$ h, 68\%. b. KOAc, DMF, 83\%. c. Red-Al, toluene, $\Delta, 93 \%$. d. $\mathrm{NCS}, \mathrm{CH}_{2} \mathrm{Cl}_{2}, \mathrm{RT}, 2$ h, 95\%. e. $\mathrm{NaOMe}, \mathrm{MeOH}, \Delta, 95 \%$. f. $\mathrm{Ac}_{2} \mathrm{O}$, pyridine, $98 \%$. g. HOAc, $\Delta$, $85 \%$. h. $\mathrm{CrO}_{3}, \mathrm{HOAc}, \Delta, 76 \%$. 
A better industrially applicable alternative may be found in the conversion of solanidine (1) to spirosolanes. In 1971 Schramm and Riedl ${ }^{26}$ already mentioned that the degradation of solanidine (1) to DPA (6) can be accomplished via the tomatidine series but up to now the complete procedure has never been published.

Therefore 3-acetoxysolanidine (11) was first submitted to the Von Braun reaction, which gave 12 in $68 \%$ yield $^{25}$ (Scheme 6). Substitution of the bromide at C16 with KOAc yielded acetate 15 in $83 \%{ }^{26}$ Subsequent reduction of $\mathbf{1 5}$ with Red-Al then gave 22 in $93 \%$ yield ${ }^{52}$. Chlorination of 22 with NCS afforded 23 in 95\% yield and elimination of $\mathrm{HCl}$ with $\mathrm{NaOMe}$ resulted in ringclosure to give tomatidenol (24) in $95 \%$ yield. ${ }^{53-58}$ Acetylation of tomatidenol with $\mathrm{Ac}_{2} \mathrm{O}$ in pyridine gave $\mathbf{2 5}$ in $98 \%$ yield. Treatment of $\mathbf{2 5}$ with HOAc at reflux temperature gave compound 26 in $85 \%$ yield. Subsequent oxidation with $\mathrm{CrO}_{3}$ in $\mathrm{HOAc}$ and elimination of the resulting C16-ester gave DPA (6) in 76\% yield. The overall yield starting from 3acetoxysolanidine (11) to DPA (6) over 9 steps was $30 \%$.

An alternative procedure for the conversion of tomatiedol (24) in DPA consists of nitrosation of tomatidenol followed by decomposition of the nitroso compound, oxidation and elimination ${ }^{59}$.

\section{Shortcuts to tomatidenol (24) starting from 3-acetoxysolanidine (11)}

To compete with existing industrial processes this route should be shortened and expensive reagents should be avoided. Shortcuts were attempted to convert compounds from the first part of the route $(\mathbf{1 1} \rightarrow \mathbf{2 4})$ to compounds from the second part of the route $(\mathbf{2 4} \rightarrow \mathbf{6})$.

A first improvement was found in the replacement of Red-Al by activated $\mathrm{Zn}$ in HOAc ${ }^{60}$ in the reduction of $\mathbf{1 5}$, which was already mentioned in a patent (Scheme 7). Best results were obtained by using freshly prepared activated $\mathrm{Zn}^{61}$ and the acetate 27 was obtained in a yield of $90 \%$. $\mathrm{LiAlH}_{4}{ }^{62}$ also reduces nitrile 15 to 22 but the yield (64\%) is lower than in the cases of RedAl or $\mathrm{Zn} /$ HOAc. $^{52}$ Chlorination of $\mathbf{2 7}$ with NCS leads to chloride $\mathbf{2 8}{ }^{63}$ in $95 \%$ yield and subsequent treatment of $\mathbf{2 8}$ with $\mathrm{NaOMe}$ in $\mathrm{MeOH}$ gives tomatidenol (24) in 95\% yield ${ }^{53-58,64,65}$.

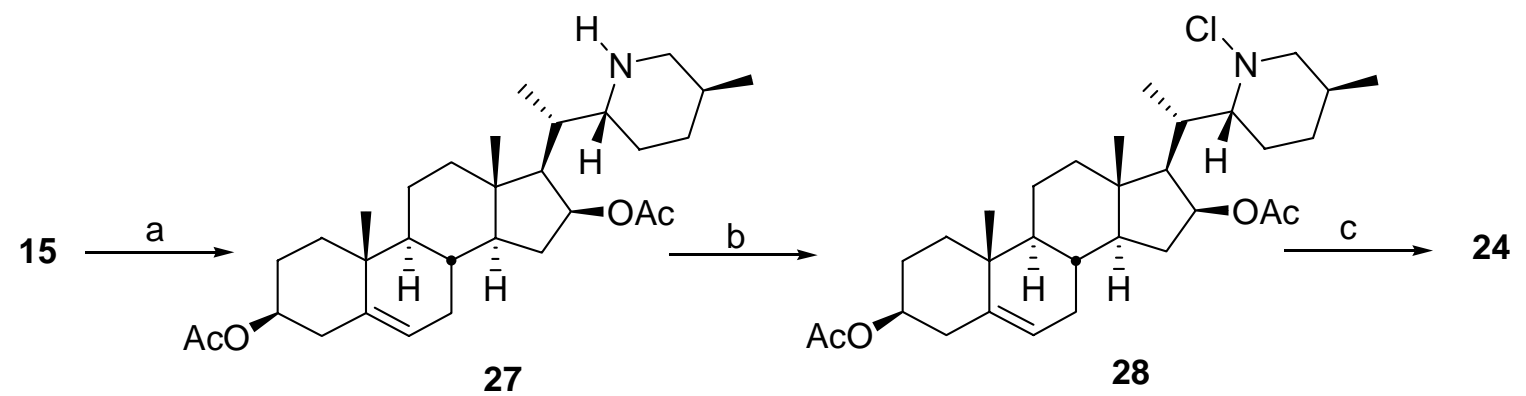

Scheme 7. a. Zn, $\mathrm{HOAc}, \mathrm{H}_{2} \mathrm{O}, 90 \%$. b. $\mathrm{NCS}, \mathrm{CH}_{2} \mathrm{Cl}_{2}$, RT, 2 h, 95\%. c. NaOMe, $\mathrm{MeOH}, \Delta, 2$ h, $95 \%$.

The chlorination/dehydrochlorination process is an economically unfavorable two-step process and direct introduction of the $\Delta^{22, \mathrm{~N}}$ double bond would be more efficient. This has been 
tried i) by elimination of HCN from 15 (Scheme 8), ii) by oxidation of amide $\mathbf{3 0}$ (Scheme 9), iii) by elimination of chlorine from $\mathbf{2 8}$, and iv) by oxidation of amine 27.

Direct elimination of the nitrile group from 15 has been tried by treatment with $\mathrm{NaOMe}$, which led to a single product that was identified as 29. A mechanistic explanation for the formation of $\mathbf{2 8}$ is depicted in Scheme $8 .^{66}$

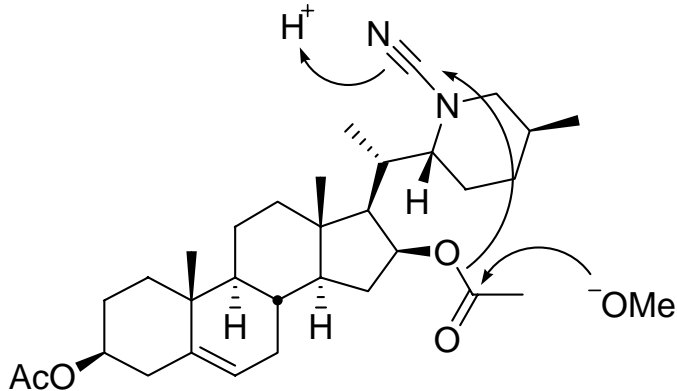

15

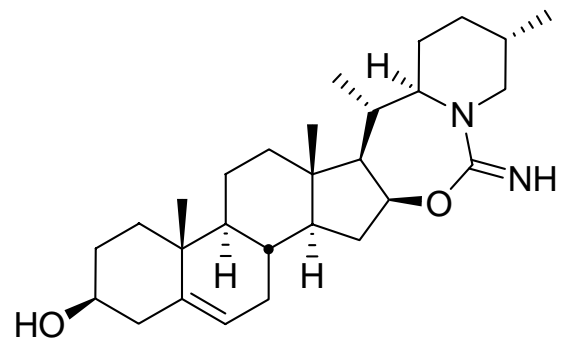

29

\section{Scheme 8}

The amide 30 could be obtained in 95\% yield by treatment of nitrile 15 with $\mathrm{Zn}$ in anhydrous HOAc. ${ }^{26,67}$ The introduction of the double bond in $\mathbf{3 0}$ was attempted with $\mathrm{CAN}^{68}, \mathrm{MnO}_{2},{ }^{10,11}$ and $\mathrm{HCl}(\text { aq. })^{69}$ but unfortunately without success.

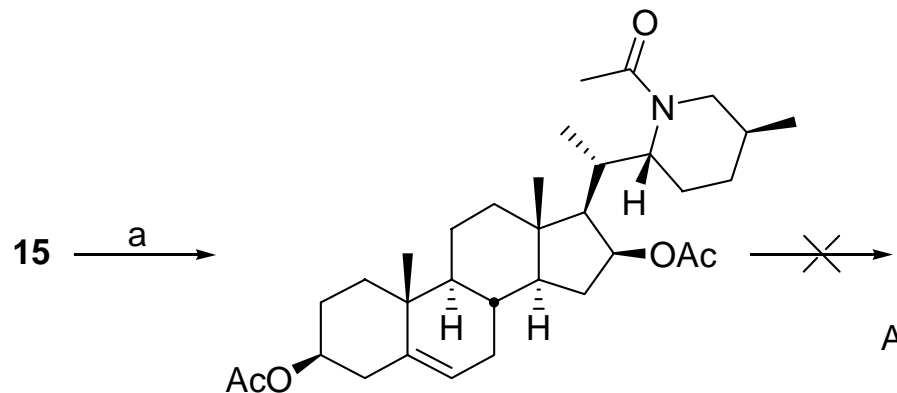

30

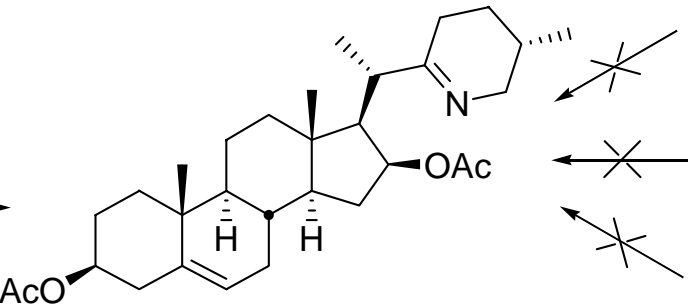

31

Scheme 9. a. HAc, Zn, 95\%.

These results indicate that an imine can only be formed by chlorination and subsequent dehydrochlorination of $\mathbf{2 8}$ with $\mathrm{NaOMe}$, but under these circumstances the acetates are saponified also, and a further reaction to tomatidenol (24) can not be avoided. To achieve formation of the $\Delta^{22(\mathrm{~N})}$ bond and to prevent further reaction to tomatidenol, it will be necessary to maintain the acetate group at $\mathrm{C} 16$. Therefore $\mathbf{2 8}$ was treated with several bases $\left(\mathrm{NaOAc} / \mathrm{EtOH}^{70}\right.$, $\mathrm{K}_{2} \mathrm{CO}_{3} / \mathrm{DMF}^{71} \mathrm{LiBr} / \mathrm{Li}_{2} \mathrm{CO}_{3} / \mathrm{DMF},{ }^{71} \mathrm{NaOMe} /$ toluene, $\mathrm{t}-\mathrm{BuOK},{ }^{72} \mathrm{Et}_{3} \mathrm{~N}^{73}{ }^{73} \mathrm{Et}_{2} \mathrm{Nli},{ }^{74} \mathrm{KHMDS},{ }^{74,75}$ $\mathrm{NaH} / \mathrm{DMSO}^{76}$ ) but all attempts were unsuccessful. It proved to be impossible to eliminate $\mathrm{HCl}$ from 28, when an acetate group at $\mathrm{C} 16$ is present ${ }^{65}$. On the other hand, elimination of $\mathrm{HCl}$ 
proved to be relatively easy if a free hydroxyl group is present at $\mathrm{C} 16$ as was demonstrated by the conversion of $\mathbf{2 3}$ to tomatidenol (24) in $73 \%$ yield with DBU. ${ }^{77}$ An intramolecualr elimination as depicted in Scheme $10^{53,54,56,58,78}$ can explain these results.

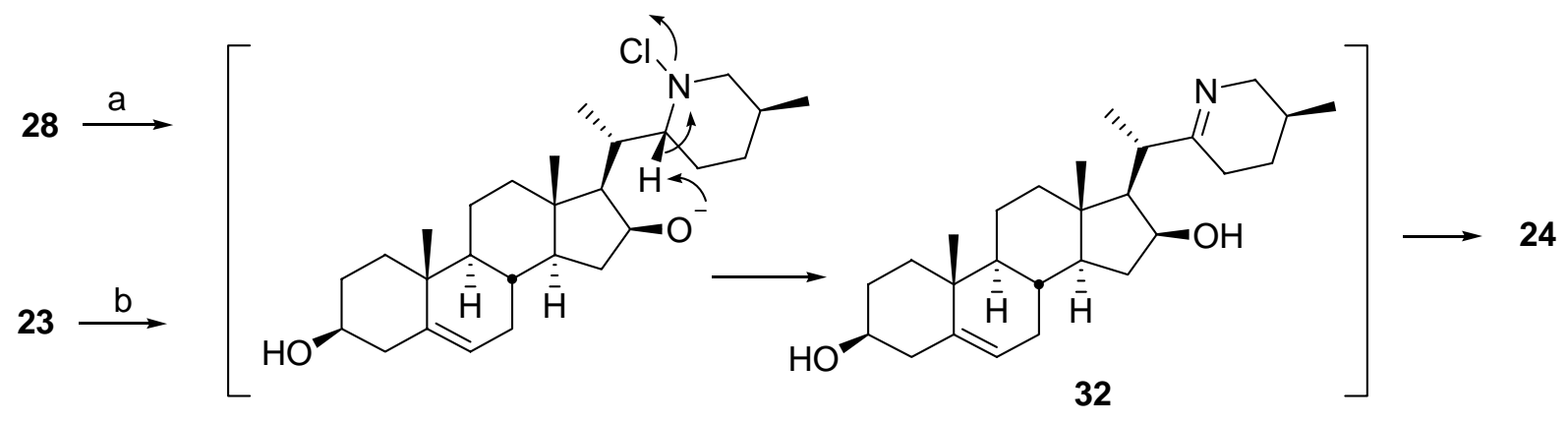

Scheme 10. a. NaOMe, $\mathrm{MeOH}, \Delta, 2$ h, 95\%. b. DBU.

Direct oxidation of 27 with $\mathrm{CrO}_{3} /$ pyridine, ${ }^{79} \mathrm{KMnO}_{4},{ }^{12} \mathrm{CAN},{ }^{68}$ or $\mathrm{KMnO}_{4} / \mathrm{Al}_{2} \mathrm{O}_{3}{ }^{68}$ was in all cases unsuccessful and only the starting material was recovered. Adam and Huong ${ }^{80}$ described several successful spirosolane formations (tomatidine (24), solasodine, soladulcidine, and solasodenone) through oxidation of the secondary amine with $\mathrm{MnO}_{2}{ }^{81}$ followed by stereospecific cyclization. ${ }^{54,82}$ However, several attempts with differently activated $\mathrm{MnO}_{2}{ }^{80,83}$ failed to give any of the desired imine 31 and only with $\mathrm{MnO}_{2}$ freshly prepared according to the method of Attenburrow et al. ${ }^{81}$ some imine 31 could be detected in the reaction mixture but the major product was still the starting material 27.

Although the diacetylated imine 31 could not be obtained from nitrile 15, amide 30, chloride 28, or amine 27, it can become available from tomatidenol (24) by treatment with $\mathrm{ZnCl}_{2}$ and $\mathrm{Ac}_{2} \mathrm{O}$ in HOAc. ${ }^{84}$ The availability of $\mathbf{3 1}$ gives the possibility to investigate two alternative degradation routes toward DPA (6). However, the limited amount of solanidine (1), available from the spray-dried protamylasse fraction, and the fact that tomatidenol (24) is not commercially available gave severe problems for further research. On the other hand, solasodine, which differs from tomatidenol only in the configuration at $\mathrm{C} 25$, is commercially available and can be considered as an acceptable model compound to investigate two alternative degradation routes toward DPA (6). Any successful results could then be repeated with tomatidenol (24) itself. Treatment of solasodine with $\mathrm{ZnCl}_{2}$ in $\mathrm{Ac}_{2} \mathrm{O}$ and $\mathrm{HOAc}$ in the same manner as previously described for tomatidenol (24) gave imine 33 in $96 \%$ yield $^{85}$ (Scheme 11).

In the first route, isomerization of the endocyclic $\Delta^{22(\mathrm{~N})}$ double bond to the exocyclic $\Delta^{20,22}$ position was achieved after methylation of $\mathbf{3 3}$ followed by treatment with aqueous $\mathrm{NaHCO}_{3}$ in acetone $^{85}$ to $\mathbf{3 4}$ in $80 \%$ overall yield (Scheme 11). Oxidation of $\mathbf{3 4}$ was attempted with $\mathrm{CrO}_{3} / \mathrm{HOAc}^{86}{ }^{8} \mathrm{KMnO}_{4} / \mathrm{Al}_{2} \mathrm{O}_{3},{ }^{13}$ ozone, ${ }^{87}$ and $\mathrm{O}_{2} / \mathrm{CuCl}^{88}$ but all attempts were unsuccessful. Hydrolysis of $\mathbf{3 4}$ with $\mathrm{HCl}$ or $\mathrm{HBr}$ in $\mathrm{HOAc}$ was tried but failed as well. The reasons for these failures are probably the same as for the oxidation of 3-acetoxysolanidi-5,20-ene (4), namely the 
steric hindrance around the $\Delta^{20,22}$ double bond. Mopac calculations on 37 indicate that it becomes difficult for other reagents to approach the $\Delta^{20,22}$ double bond due to C18, the F-ring itself, and the $N$-methyl. Similar negative results were found by Sato and Ikekawa in their attempt to oxidize a compound similar to $\mathbf{3 4}$ with an acetyl instead of a methyl group attached to the nitrogen. ${ }^{89}$

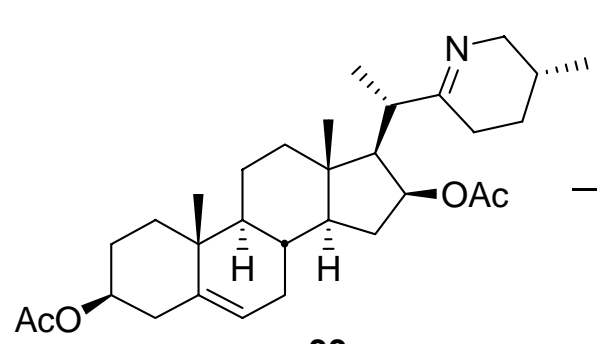

33

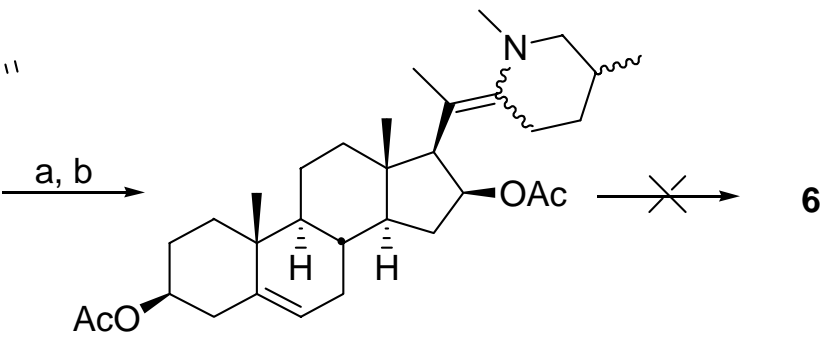

34

Scheme 11. a. MeI, benzene, acetone, $\Delta, 3$ h, $82 \%$. b. $\mathrm{NaHCO}_{3}$, acetone, $97 \%$.

Treatment of $\mathbf{3 3}$ with $\mathrm{Ac}_{2} \mathrm{O}$ and pyridine acetylates the nitrogen and simultaneously shifts the $\Delta^{22(\mathrm{~N})}$ double bond to the $\Delta^{22,23}$ position yielding the thermodynamic compound 35 quantitatively $^{89,90}$ (Scheme 12). Mild hydrolysis of $\mathbf{3 5}$ with aqueous $\mathrm{HCl}$ and HOAc gives 36 in quantitative yield. ${ }^{89,90}$ Deprotection of the $\mathrm{C} 16$ acetate with methanolic $\mathrm{K}_{2} \mathrm{CO}_{3}$ followed by addition of HOAc gave a $82 \%$ yield of 37 instead of the expected $26 .{ }^{89}$ A renewed attempt to eliminate $\mathrm{MeOH}$ from 37 with $\mathrm{HOAc}$ at reflux temperature also failed.

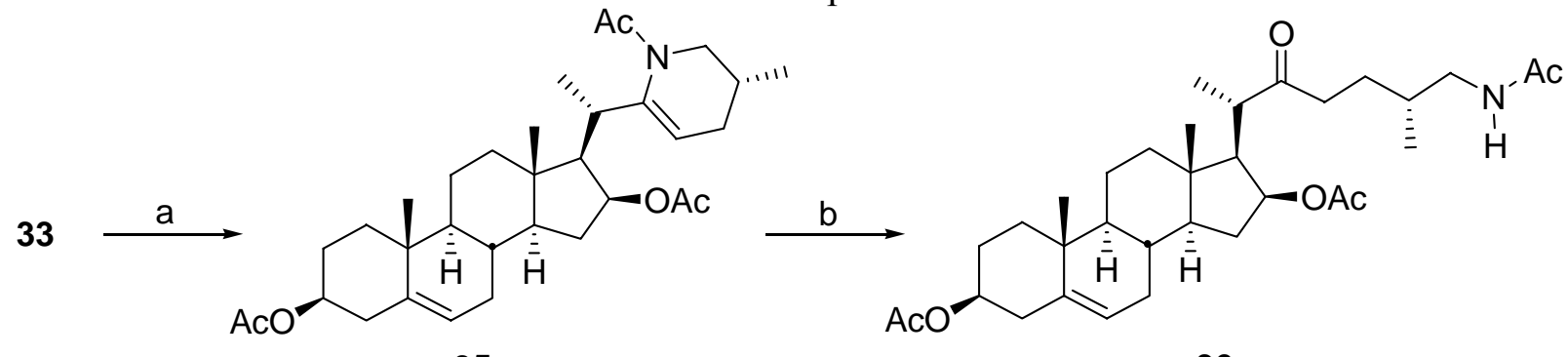

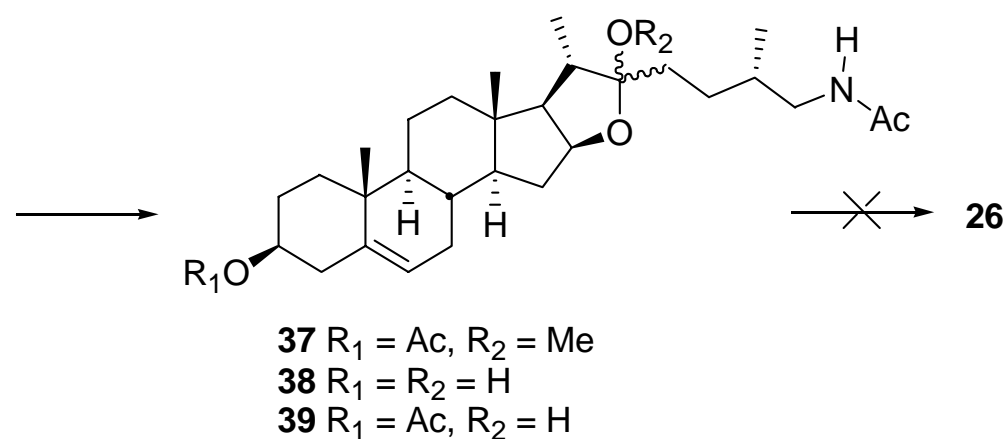

Scheme 12. a. $\mathrm{Ac}_{2} \mathrm{O}$, pyridine, RT, 4 days, $99 \%$. b. $\mathrm{HCl}, \mathrm{HOAc}, 99 \%$. $\mathrm{c}_{\mathrm{i}} . \mathrm{K}_{2} \mathrm{CO}_{3}, \mathrm{MeOH}, 82 \%$ (40). $\mathrm{c}_{\mathrm{ii}} \cdot \mathrm{K}_{2} \mathrm{CO}_{3}, \mathrm{EtOH}, 78 \%$ (40). $\mathrm{c}_{\mathrm{iii}}$. $\mathrm{NaOH}$, dioxane, $78 \%$ (40). 
Treatment of $\mathbf{3 6}$ with $\mathrm{K}_{2} \mathrm{CO}_{3}$ in a mixture of water and $\mathrm{EtOH}$ overnight gave hemiacetal $\mathbf{3 8}$ in $78 \%$ yield. The formation of $\mathbf{3 8}$ in about the same yield was also achieved upon treatment of $\mathbf{3 6}$ with $\mathrm{NaOH}$ in dioxane. In this case the elimination of water from 38 with HOAc at reflux temperature $^{89}$ also failed. This result is in agreement with that of Cambie et al., ${ }^{91}$ who was not able to dehydrate compound 39. However a similar dehydration could be achieved by Sato and Ikekawa. ${ }^{89}$ It thus turned out that properties of imine $\mathbf{3 3}$ as an intermediate in the synthesis of DPA (6) were not redeemed. Despite all our efforts, shortening of the route from 3acetoxysolanidine (11) via tomatidenol (24) to DPA (6) as depicted in Scheme 6, could not be accomplished.

\section{Experimental Section}

General Procedures. Dry reactions were performed under a steady stream of dry nitrogen or argon with glassware dried at $140{ }^{\circ} \mathrm{C}$. All ${ }^{1} \mathrm{H}$ and ${ }^{13} \mathrm{C}$ NMR spectra were measured with a Bruker AC-E 200 spectrometer. $400 \mathrm{MHz}{ }^{1} \mathrm{H}$ and $100 \mathrm{MHz}{ }^{13} \mathrm{C}$ NMR were measured with a DPX 400 spectrometer. Chemical shifts are reported in parts per million $(\delta)$ relative to tetramethylsilane $(\delta$ 0.0). MS and HRMS data were obtained with a Finnigan Mat 95 spectrometer. FT-IR spectra were measured with a BIO-RAD FTS-7 infra-red spectrometer. Optical rotations were measured with a Perkin-Elmer 241 polarimeter with the concentrations denoted in units of $\mathrm{g} / 100 \mathrm{ml}$. Analytical data were obtained using a Carlo Erba Elemental Analyzer 7206. Melting points are uncorrected. Solvents were freshly distilled by common practice. Product solutions were dried over $\mathrm{Na}_{2} \mathrm{SO}_{4}$ prior to evaporation of the solvent under reduced pressure by using a rotary evaporator. For flash chromatography, Merck Kieselgel silica 60 (230-400 Mesh) or Baker Alumina was used. Reactions were monitored with TLC using Merck silica gel 60F254 plastic sheets. Compounds were visualized on TLC by UV detection and by spraying with acid and subsequent heating.

\section{Isolation of $\alpha$-chaconine (6) and $\alpha$-solanine (7) according to Friedman et al ${ }^{2}$}

Spray-dried protamylasse (39.4 g) was dissolved in diluted acetic acid (120 ml, 1\%) and stirred for 10 minutes at room temperature. The solution was made basic with $\mathrm{NH}_{4} \mathrm{OH}$ to $\mathrm{pH} 9 \sim 10$, heated at $70^{\circ} \mathrm{C}$ for 30 minutes, and stored overnight at $4^{\circ} \mathrm{C}$. The mixture was then centrifuged (3161 rpm) for 50 minutes and the supernatant was discarded. The solid pellet was washed with cold aqueous $\mathrm{NH}_{4} \mathrm{OH}(2 \%)$ and recentrifuged $(3161 \mathrm{rpm})$ for 30 minutes. The pellet was taken up in a mixture of EtOAc/EtOH/ $\mathrm{NH}_{4} \mathrm{OH}(5 \%)(250 \mathrm{ml}, 80 / 16 / 4)$ and filtered. The remaining filter cake was extracted twice with EtOAc/EtOH/ $\mathrm{NH}_{4} \mathrm{OH}(5 \%)(250 \mathrm{ml}, 80 / 16 / 4)$. The combined filtrates were evaporated under reduced pressure to afford a yellow solid (3.0 g). Crystallization from ethanol (80\%) gave $2.16 \mathrm{~g}$ of a mixture of 6 and 7. 
MS m/z (r.i.) $870.4\left(\mathrm{MH}^{+}+2, \alpha\right.$-solanine), $869.5\left(\mathrm{MH}^{+}+1, \alpha\right.$-solanine), $868.5\left(\mathrm{MH}^{+}, \alpha\right.$-solanine), $854.5\left(\mathrm{MH}^{+}+2, \alpha\right.$-chaconine $), 853.5\left(\mathrm{MH}^{+}+1, \alpha\right.$-chaconine $), 852.5\left(\mathrm{MH}^{+}, \alpha\right.$-chaconine $), 723.5$ $\left(\mathrm{MH}^{+}+1, \beta_{2}\right.$-solanine), $722.5\left(\mathrm{MH}^{+}, \beta_{2}\right.$-solanine $), 707.5\left(\mathrm{MH}^{+}+1, \beta\right.$-chaconine $), 706.5\left(\mathrm{MH}^{+}, \beta\right.$ chaconine), $561.5\left(\mathrm{MH}^{+}, \gamma\right.$-chaconine $), 560.5\left(\mathrm{MH}^{+}, \gamma\right.$-chaconine $), 399.6\left(\mathrm{MH}^{+}+1\right.$, solanidine $)$, $398.5\left(\mathrm{MH}^{+}\right.$, solanidine $)$

\section{Isolation of solanidine (1) and solanida-3,5-diene}

The spray-dried potato protein $(225 \mathrm{~g})$ was dissolved in water $(700 \mathrm{ml})$, made basic with $\mathrm{NH}_{4} \mathrm{OH}$ $(35 \%)$ to $\mathrm{pH} 10-12$, and stored overnight at $4^{\circ} \mathrm{C}$. The solution was then centrifuged (6000 rpm) for 30 minutes and the supernatant was discarded. The crude glycoalkaloid mixture was transferred to a Soxhlett apparatus and extracted with ethanol for 24 hours. After evaporation, the resulting brown solid was dissolved in ethanol $(350 \mathrm{ml})$ and hydrolyzed with aqueous $\mathrm{HCl}(37 \%$, $40 \mathrm{ml}$ ) at reflux temperature for 3 hours. The solution was cooled to room temperature and made basic with $\mathrm{NH}_{4} \mathrm{OH}(35 \%)$. The solvent was evaporated to yield a brown solid, which was taken up in $\mathrm{H}_{2} \mathrm{O}(250 \mathrm{ml})$ and $\mathrm{CHCl}_{3}(250 \mathrm{ml})$. The water layer was extracted three times with $\mathrm{CHCl}_{3}$ $(200 \mathrm{ml})$ and the combined organic extracts were dried and flash chromatographed $\left(\mathrm{Al}_{2} \mathrm{O}_{3}\right.$, $\mathrm{CHCl}_{3} / \mathrm{MeOH}$ 9/1) to give a crude mixture of 1 and solanida-3,5-diene. Crystallization from the eluent gave 1 ( $2.47 \mathrm{~g})$. After concentration of the mother liquor, crystallization of the remaining residue from EtOH (96\%) provided solanid-3,5-diene $(0.51 \mathrm{~g})$.

NMR and mass spectral data of solanidine ${ }^{92}$ and solanid-3,5-diene ${ }^{93}$ are in accordance with literature data.

3ß-Acetoxysolanidine (11). The NMR spectral data for 11 were identical to those reported in literature. $^{92}$

3及-Acetoxy-5,20(22)-solanidiene (4). The ${ }^{1} \mathrm{H} N M R$ spectral data of $\mathbf{4}$ were identical to those reported in literature. ${ }^{5}$

Solanid-4-en-3-one (7). A solution of $1(0.51 \mathrm{~g}, 1.27 \mathrm{mmol})$ in toluene $(150 \mathrm{ml})$ and cyclohexanone $(25 \mathrm{ml})$ was stirred. Then $\mathrm{Al}(\mathrm{i}-\mathrm{OPr})_{3}(0.54 \mathrm{~g}, 2.67 \mathrm{mmol})$ was added and the mixture was refluxed overnight. After cooling to room temperature, the reaction mixture was quenched with a saturated aqueous solution of $\mathrm{NaHCO}_{3}$ and extracted three times with EtOAc. The combined organic layers were washed with brine, dried, and evaporated to give a brown oil $(0.54 \mathrm{~g})$. The brown oil was flash chromatographed $\left(\mathrm{CHCl}_{3} / \mathrm{MeOH} 9 / 1\right)$ to give $7(0.36 \mathrm{~g}, 72 \%)$ as a white solid. M.p. $218^{\circ} \mathrm{C}$ (lit. $218^{\circ} \mathrm{C}^{94}$ ); ${ }^{1} \mathrm{H}$ NMR $\delta 0.74(\mathrm{~s}, 3 \mathrm{H}), 0.79$ (d, $\left.3 \mathrm{H}, J=6.4 \mathrm{~Hz}\right), 0.85$ $(\mathrm{d}, 3 \mathrm{H}, J=5.7 \mathrm{~Hz}), 1.14$ (s, 3H), 5.67 (d, 1H, $J=1.5 \mathrm{~Hz}) ;{ }^{13} \mathrm{C} \operatorname{NMR} \delta 16.92$ (q), 17.41 (q), 18.26 $(\mathrm{q}), 19.54(\mathrm{q}), 20.84(\mathrm{t}), 29.25(\mathrm{t}), 31.04(\mathrm{~d}), 31.16(\mathrm{t}), 32.14(\mathrm{t}), 32.93(\mathrm{t}), 33.30(\mathrm{t}), 33.97(\mathrm{t})$, 35.41 (d), 35.70 (t), 36.62 (d), $38.66(\mathrm{~s}), 39.77$ (t), 40.37 (s), 53.90 (d), 56.71 (d), 60.14 (t), 62.87 (d), 68.86 (d), 75.55 (d), 123.76 (d), 171.51 (s), 199.56 (s); MS m/z (r.i.) 395 (50), 380 (9), 204 (25), 150 (100); HRMS calculated for $\mathrm{C}_{27} \mathrm{H}_{41} \mathrm{NO}\left(\mathrm{M}^{+}\right)$395.3188, found 395.3181 . 
Solanidan-4-en-3-one $\mathbf{N}$-oxide (8). To a solution of 89 (130.1 mg, $0.33 \mathrm{mmol})$ in $\mathrm{CH}_{2} \mathrm{Cl}_{2}$ (5 ml) was added a solution of MMPP $(223.2 \mathrm{mg}, 0.45 \mathrm{mmol})$ in $\mathrm{CH}_{2} \mathrm{Cl}_{2} / \mathrm{H}_{2} \mathrm{O}$ 1/1 (11 ml). After 12 hours in the dark, the reaction mixture was quenched with saturated aqueous $\mathrm{Na}_{2} \mathrm{~S}_{2} \mathrm{O}_{3}$ and extracted twice with $\mathrm{CH}_{2} \mathrm{Cl}_{2}$. The combined organic layers were dried and the solvent evaporated in vacuo. The remaining residue was flash chromatographed (EtOAc/ $\mathrm{MeOH}$ 9/1) yielding 98 (69.0 mg, 53\%) as a white solid. M.p. $197-200^{\circ} \mathrm{C} ;{ }^{1} \mathrm{H} \mathrm{NMR}\left(\mathrm{CDCl}_{3} / \mathrm{CD}_{3} \mathrm{OD}\right) \delta 0.86(\mathrm{~d}, 1 \mathrm{H}, J=$ $6.1 \mathrm{~Hz}) 0.96(\mathrm{~d}, 3 \mathrm{H}, J=6.6 \mathrm{~Hz}), 1.13(\mathrm{~s}, 3 \mathrm{H}), 1.19(\mathrm{~s}, 3 \mathrm{H}), 2.74(\mathrm{dt}, 1 \mathrm{H}, J=10.3$ and $2.3 \mathrm{~Hz})$, $3.35(\mathrm{~d}, 1 \mathrm{H}, J=6.9 \mathrm{~Hz}), 3.73(\mathrm{~m}, 1 \mathrm{H}), 5.71(\mathrm{~d}, 1 \mathrm{H}, J=0.9 \mathrm{~Hz}) ;{ }^{13} \mathrm{C} \mathrm{NMR}\left(\mathrm{CDCl}_{3} / \mathrm{CD}_{3} \mathrm{OD}\right) \delta$ $14.65(\mathrm{q}), 16.29(\mathrm{q}), 17.29(\mathrm{q}), 18.32(\mathrm{q}), 20.90(\mathrm{t}), 21.92(\mathrm{t}), 23.61(\mathrm{t}), 26.30(\mathrm{~d}), 31.56(\mathrm{t}), 23.12$ $(\mathrm{t}), 32.68(\mathrm{t}), 33.82(\mathrm{~d}), 33.89(\mathrm{t}), 34.74(\mathrm{~d}), 35.60(\mathrm{t}), 38.61(\mathrm{~s}), 39.91(\mathrm{~s}), 40.08(\mathrm{t}), 53.70(\mathrm{~d})$, 56.24 (d), 61.32 (d), 71.21 (t), 81.25 (d), 83.49 (d), 123.76 (d), 171.11 (s), 199.52 (s).

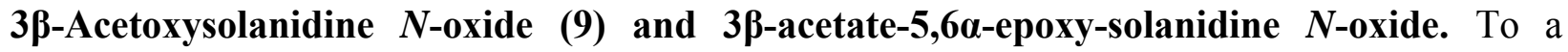
solution of 11 (4.89 g, $11.14 \mathrm{mmol})$ in $\mathrm{CH}_{2} \mathrm{Cl}_{2} / \mathrm{MeOH} 2 / 1(750 \mathrm{ml})$ was added a suspension of $70-75 \%$ mCPBA $(5.45 \mathrm{~g}, 22.11 \mathrm{mmol})$ in $\mathrm{CH}_{2} \mathrm{Cl}_{2}(200 \mathrm{ml})$. After 18 hours in the dark, the reaction mixture was concentrated, washed with a dilute solution of $\mathrm{NaHCO}_{3}$, dried, and evaporated in vacuo. Repeated flash chromatography $\left(\mathrm{CHCl}_{3} / \mathrm{MeOH} 9 / 1\right)$ of the amorphous

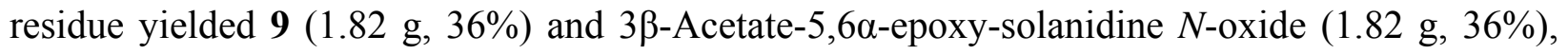
both as white solids.

9. ${ }^{1} \mathrm{H}$ NMR $\delta 0.65(\mathrm{~d}, 3 \mathrm{H}, J=6.2 \mathrm{~Hz}), 0.73(\mathrm{~d}, 3 \mathrm{H}, J=6.6 \mathrm{~Hz}), 0.78(\mathrm{~s}, 3 \mathrm{H}), 0.80(\mathrm{~s}, 3 \mathrm{H}), 1.78(\mathrm{~s}$, $3 \mathrm{H}), 3.14(\mathrm{~d}, 1 \mathrm{H}, J=9.6 \mathrm{~Hz}), 3.47(1 \mathrm{H}), 4.32(\mathrm{~m}, 1 \mathrm{H}), 5.12(\mathrm{br} \mathrm{d}, 1 \mathrm{H}, J=3.8 \mathrm{~Hz}) ;{ }^{13} \mathrm{C} \mathrm{NMR} \delta$ 14.56 (q), 16.38 (q), 18.38 (q), 19.27 (q), $20.96(\mathrm{t}), 21.43$ (q), 21.93 (t), 23.69 (t), 26.29 (d), $27.68(\mathrm{t}), 31.04(\mathrm{~d}), 31.66(\mathrm{t}), 31.91(\mathrm{t}), 32.03(\mathrm{t}), 33.82(\mathrm{~d}), 36.69(\mathrm{~s}), 36.93(\mathrm{t}), 38.03(\mathrm{t}), 39.84$ $(\mathrm{s}), 40.28(\mathrm{t}), 49.94(\mathrm{~d}), 57.11(\mathrm{~d}), 61.51$ (d), 71.25 (t), 73.83 (d), 81.45 (d), 83.56 (d), 122.21 (d), $139.70(\mathrm{~s}), 170.57(\mathrm{~s})$.

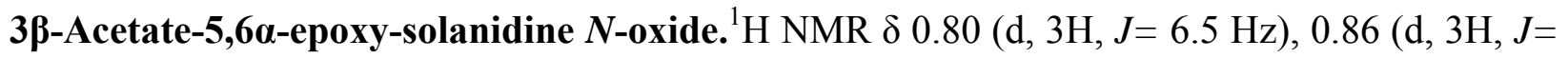
$6.6 \mathrm{~Hz}), 0.90(\mathrm{~s}, 3 \mathrm{H}), 0.98(\mathrm{~s}, 3 \mathrm{H}), 1.92(\mathrm{~s}, 3 \mathrm{H}), 3.68(\mathrm{~m}, 1 \mathrm{H}), 4.92(\mathrm{~m}, 1 \mathrm{H}) ;{ }^{13} \mathrm{C}$ NMR $\delta 14.46$ (q), 15.95 (q), 17.81 (q), 20.73 (2q), 21.14 (d), 21.48 (q), 23.44 (t), 26.11 (d), 26.31 (t), 29.32 (t), $31.08(\mathrm{~d}), 32.04(\mathrm{t}), 33.57(\mathrm{~d}), 35.36(\mathrm{t}), 37.26(\mathrm{t}), 38.91(\mathrm{~s}), 40.02(\mathrm{t}+\mathrm{s}), 44.67(\mathrm{t}), 49.99(\mathrm{~d})$, 55.38 (d), 61.06 (d), 63.45 (d), 70.43 (t), 71.59 (t), 75.23 (s), 81.44 (d), 83.53 (d), $171.76(\mathrm{~s})$.

(3ß)-Acetoxy-23-trifluoroacetylsolanid-5,22-diene (10). To a solution of 7 (100.3 mg, $0.22 \mathrm{mmol})$ in THF $(2 \mathrm{ml})$ was added $\left(\mathrm{CF}_{3} \mathrm{CO}\right)_{2} \mathrm{O}(35 \mu \mathrm{l}, 0.24 \mathrm{mmol})$ under argon atmosphere. The solution colored immediately yellow and then slowly to orange. After 30 minutes, $t$-BuOK $(60.6 \mathrm{mg}, 0.51 \mathrm{mmol})$ was added and the solution was stirred for 16 hours. The reaction mixture was diluted with $\mathrm{H}_{2} \mathrm{O}$, and extracted three times with $\mathrm{CHCl}_{3}(50 \mathrm{ml})$. The combined organic extracts were washed with saturated aqueous $\mathrm{NaHCO}_{3}$, dried, and evaporated in vacuo. Flash chromatography of the remaining residue (EtOAc/PE 9/1) yielded $\mathbf{1 0}(45.9 \mathrm{mg}, 41 \%)$ as an orange oil. ${ }^{1} \mathrm{H}$ NMR (main peaks) $\delta 0.60(\mathrm{~s}, 3 \mathrm{H}), 1.03(\mathrm{~s}, 3 \mathrm{H}), 1.03(\mathrm{~d}, 3 \mathrm{H}, J=6.4 \mathrm{~Hz}), 1.19$ (d, $3 \mathrm{H}, J=6.9 \mathrm{~Hz}$ ), 2.05 (s, 3H), 2.29 (br d, $1 \mathrm{H}, J=15.0 \mathrm{~Hz}), 2.78$ (dd, $1 \mathrm{H}, J=8.2$ and $12.9 \mathrm{~Hz}), 3.31$ (dd, $1 \mathrm{H}, J=4.3$ and $12.9 \mathrm{~Hz}), 3.90$ (q, 1H, $J=6.9 \mathrm{~Hz}$ ), 4.21 (ddd, 1H, $J=5.6,7.9$, and 7.9 Hz), 
$4.61(\mathrm{~m}, 1 \mathrm{H}), 5.38$ (br d, 1H, $J=5.2 \mathrm{~Hz}) ;{ }^{13} \mathrm{C} \mathrm{NMR} \delta 13.81(\mathrm{q}), 18.67$ (q), 19.73 (q), 20.16 (q), $20.74(\mathrm{t}), 21.82(\mathrm{q}), 26.59(\mathrm{~d}), 28.10(\mathrm{t}), 29.05(\mathrm{t}), 31.41(\mathrm{t}), 31.76(\mathrm{~d}), 32.32(\mathrm{t}), 37.07(\mathrm{~s}), 37.35$ $(\mathrm{t}), 38.47(2 \mathrm{t}), 39.61(\mathrm{~d}), 42.13(\mathrm{~s}), 49.81$ (t), 50.43 (d), 55.38 (d), 60.07 (d), 67.36 (d), 74.17 (d), 90.93 (s), 116.21 (q, $J=285 \mathrm{~Hz}$ ), 122.23 (d), 140.42 (s), 170.98 (s), 172.32 (s). The chemical shift of the quartet signal for the $\mathrm{C}=\mathrm{O}$ group of the trifluoroacetyl moiety could not be determined because its intensity was too low. MS m/z (r.i.) $534\left(\mathrm{M}^{+}+1,35\right), 533\left(\mathrm{M}^{+}, 100\right), 465$ (28), $464\left(\mathrm{M}^{+}-\mathrm{HCF}_{3}, 89\right), 404$ (17), 258 (22), 195 (9), 69 (11), 43 (9); HRMS calculated for $\mathrm{C}_{31} \mathrm{H}_{42} \mathrm{~F}_{3} \mathrm{NO}_{3}\left(\mathrm{M}^{+}\right)$533.3117, found 533.3120.

$(3 \beta, 16 \alpha, 20 S)-16-B r o m o-20-[(2 R, 5 S)-1-c y a n o-5-m e t h y l p i p e r i d i n y l] p r e g n-5-e n-3-y l \quad$ acetate $(12)^{95}$ and $(2 S, 4 \mathrm{a} R, 4 \mathrm{bS}, 6 \mathrm{a} S, 6 \mathrm{~b} R, 7 S, 9 \mathrm{a} S, 10 \mathrm{a} S, 10 \mathrm{bS})-8-[(3 R)-4-b r o m o-3-m e t h y l b u t y l]-9-$ cyano-4a,6a,7-trimethyl-1,2,3,4,4a,4b,5,6,6a,6b,7,8,9,9a,10,10a,10b,11-

octadecahydronaphtho- $\left[2^{\prime}, 1^{\prime}: 4,5\right]$ indeno[2,1-b]pyrrol-2-yl acetate (13). A solution of 11 (0.9 $\mathrm{g}, 2.05 \mathrm{mmol})$ in $\mathrm{CHCl}_{3}(20 \mathrm{ml})$ was treated with a $3 \mathrm{M}$ solution of $\mathrm{BrCN}(5 \mathrm{ml}, 15.00 \mathrm{mmol})$ in $\mathrm{CHCl}_{3}$. After heating at reflux temperature for 24 hours under nitrogen atmosphere, the solvent was removed in vacuo and the remaining gum crystallized from PE/EA 1/1 to give 12 (0.5 g, $45 \%$ ). The mother liquor was purified by column chromatography (PE/EA 5/1) to give additional $12(0.255 \mathrm{~g}, 23 \%)$ and the F-ring opened product $13(0.135 \mathrm{~g}, 12 \%)$.

12. M.p. $250-260^{\circ} \mathrm{C}(\mathrm{EtOH})$ (lit. $245-260^{\circ} \mathrm{C}^{95}$ ); IR ${ }^{95} v_{\max }$ (neat) $1717,2199,2841,2911,2932 \mathrm{~cm}^{-}$ '; ${ }^{1} \mathrm{H}$ NMR $\delta 0.72(\mathrm{~s}, 3 \mathrm{H}), 0.85(\mathrm{~d}, 3 \mathrm{H}, J=6.5 \mathrm{~Hz}), 0.96(\mathrm{~d}, 3 \mathrm{H}, J=7.7 \mathrm{~Hz}), 0.98(\mathrm{~s}, 3 \mathrm{H}), 2.00(\mathrm{~s}$, $3 \mathrm{H}), 2.29(\mathrm{~d}, 2 \mathrm{H}, J=7.5 \mathrm{~Hz}), 2,72(\mathrm{t}, 1 \mathrm{H}, J=11.0 \mathrm{~Hz}), 3.17(\mathrm{~d}, 1 \mathrm{H}, J=11.0 \mathrm{~Hz}), 3.38(\mathrm{dd}, 1 \mathrm{H}, J=$ 3.3 and $10.9 \mathrm{~Hz}), 4.04(\mathrm{t}, 1 \mathrm{H}, J=6.2 \mathrm{~Hz}), 4.57(\mathrm{~m}, 1 \mathrm{H}), 5.34(\mathrm{~d}, 1 \mathrm{H}, J=4.1 \mathrm{~Hz}) ;{ }^{13} \mathrm{C}$ NMR $\delta$ 12.50 (q), 13.98 (q), $18.63(\mathrm{q}), 19.23(\mathrm{q}), 20.72(\mathrm{t}), 21.40(\mathrm{q}), 23.76(\mathrm{t}), 27.63$ (t), $30.54(2 \mathrm{~d})$, $31.58(\mathrm{t}), 31.68(\mathrm{t}), 36.46(\mathrm{~s}), 36.82(\mathrm{t}), 37.08(\mathrm{~d}), 37.97(\mathrm{t}), 39.51(\mathrm{t}), 39.67(\mathrm{t}), 45.16(\mathrm{~s}), 49.47$ (d), 53.15 (d), 54.16 (d), 58.25 (t), 60.08 (d), 63.77 (d), 73.72 (d), 117.08 (s), 121.97 (d), 139.64 (s), 170.48 (s) ); MS m/z (r.i.) 425 (8), 410 (7), 124 (14), 112 (100), 98 (31), 58 (71); HRMS calculated for $\mathrm{C}_{28} \mathrm{H}_{41} \mathrm{~N}_{2} \mathrm{Br}\left([\mathrm{M}-\mathrm{HOAc}]^{+}\right)$484.2453, found 484.2454. The ${ }^{1} \mathrm{H}$ NMR data were in accordance with the literature data ${ }^{2.5}$

13. ${ }^{1} \mathrm{H}$ NMR $\delta 0.77$ (s, 3H), $0.98(2 \mathrm{~s}, 6 \mathrm{H}), 0.99$ (d, 3H, $\left.J=6.4 \mathrm{~Hz}\right), 1.97$ (s, 3H), 3.32 (d, 2H, $J=$ $5.4 \mathrm{~Hz}), 3.87(\mathrm{~m}, 1 \mathrm{H}), 4.53(\mathrm{~m}, 1 \mathrm{H}), 5.31(\mathrm{~d}, 1 \mathrm{H}, J=4.3 \mathrm{~Hz}) ;{ }^{13} \mathrm{C} \mathrm{NMR} d 16.09$ (q), 18.54 (q), $19.13(\mathrm{q}), 20.11(\mathrm{q}), 20.32(\mathrm{t}), 21.28(\mathrm{q}), 27.53(\mathrm{t}), 28.18(\mathrm{t}), 29.63(\mathrm{t}), 31.10(\mathrm{t}), 31.26(\mathrm{~d}), 31.64$ $(\mathrm{t}), 35.00(\mathrm{~d}), 35.42(\mathrm{~d}), 36.47(\mathrm{~s}), 36.78(\mathrm{t}), 37.87(\mathrm{t}), 38.83(\mathrm{t}), 40.71(\mathrm{t}), 41.28(\mathrm{~s}), 49.63(\mathrm{~d})$, 56.95 (d), 61.18 (d), 65.21 (d), 72.12 (d), 73.56 (d), 116.19 (s), 121.93 (d), 139.52 (s), 170.30 (s) ); MS m/z (r.i.) 484 (18), 439 (5), 405 (5), 150 (21), 123 (100); HRMS calculated for $\mathrm{C}_{28} \mathrm{H}_{41} \mathrm{~N}_{2} \mathrm{Br}\left([\mathrm{M}-\mathrm{HOAc}]^{+}\right)$484.2453, found 484.2441.

(3ß,20S)-20-[(2R,5S)-1-Cyano-5-methylpiperidinyl]pregn-5-en-3-yl acetate (14). A solution of $12(0.20 \mathrm{~g}, 0.37 \mathrm{mmol}), \mathrm{Bu}_{3} \mathrm{SnH}(0.15 \mathrm{ml}, 0.56 \mathrm{mmol})$, and AIBN (cat. amount) in benzene $(5 \mathrm{ml})$ was heated at reflux temperature for 7.5 hours under a nitrogen atmosphere. ${ }^{96}$ After cooling and concentration of the mixture in vacuo, ether $(25 \mathrm{ml})$ and saturated aqueous $\mathrm{KF}$ $(25 \mathrm{ml})$ were added and the mixture was stirred overnight at room temperature. The layers were 
separated and the aqueous phase was extracted three times with chloroform $(25 \mathrm{ml})$. The combined organic phases were washed with brine, dried, and concentrated in vacuo. Purification of the residue by flash chromatography (PE/EA 9/1) gave $14(0.11 \mathrm{~g}, 64 \%)$ as a white solid. ${ }^{1} \mathrm{H}$ NMR $\delta 0.66(\mathrm{~s}, 3 \mathrm{H}), 0.80(\mathrm{~d}, 3 \mathrm{H}, J=6.6 \mathrm{~Hz}), 0.92(\mathrm{~d}, 3 \mathrm{H}, J=6.7 \mathrm{~Hz}), 0.95(\mathrm{~s}, 3 \mathrm{H}), 1.97(\mathrm{~s}, 3 \mathrm{H})$, $2.25(\mathrm{~d}, 2 \mathrm{H}, J=7.9 \mathrm{~Hz}), 2.62(\mathrm{t}, 1 \mathrm{H}, J=11.6 \mathrm{~Hz}), 2.76(\mathrm{~d}, 1 \mathrm{H}, J=8.9 \mathrm{~Hz}), 3.32$ (dd, $1 \mathrm{H}, J=2.4$ and $11.7 \mathrm{~Hz}), 4.50(\mathrm{~m}, 1 \mathrm{H}), 5.30(\mathrm{~d}, 1 \mathrm{H}, J=4.3 \mathrm{~Hz}) ;{ }^{13} \mathrm{C} \mathrm{NMR} \delta 11.81(\mathrm{q}), 13.65(\mathrm{q}), 18.72(\mathrm{q})$, $19.32(\mathrm{q}), 21.00(\mathrm{t}), 21.47(\mathrm{q}), 23.33(\mathrm{t}), 24.23(2 \mathrm{t}), 27.56(\mathrm{t}), 27.74(\mathrm{t}), 30.64(\mathrm{~d}), 31.83$ (d), $32.34(\mathrm{t}), 36.56(\mathrm{~s}), 36.98(\mathrm{t}), 37.34(\mathrm{~d}), 38.09(\mathrm{t}), 39.69(\mathrm{t}), 42.69(\mathrm{~s}), 49.98(\mathrm{~d}), 52.68(\mathrm{~d}), 56.44$ (d), 58.17 (t), 60.40 (d), 73.92 (d), 117.29 (s), 122.42 (d), 139,73 (s), 170.59 (s).

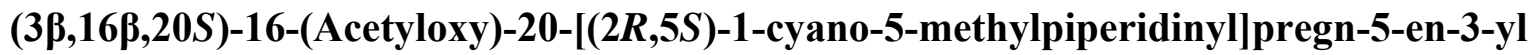

acetate (15). To a solution of $12(0.4 \mathrm{~g}, 0.73 \mathrm{mmol})$ in DMF $(40 \mathrm{ml})$ was added an aqueous KOAc solution $(40 \%, 1.33 \mathrm{ml})$. The reaction mixture was heated at $90^{\circ} \mathrm{C}$ for 2 hours and then poured into water. The water layer was extracted three times with ether $(15 \mathrm{ml})$. The combined organic layers were washed with water, dried and evaporated in vacuo yielding a white solid. Flash chromatography (PE/EA 5/1) yielded $15(0.32 \mathrm{~g}, 83 \%)$ as a white solid. M.p. $163-167^{\circ} \mathrm{C}$ $\left(160-167^{\circ} \mathrm{C}^{52}\right) ;{ }^{1} \mathrm{H}$ NMR $\delta 0.79(\mathrm{~d}, 3 \mathrm{H}, J=6.5 \mathrm{~Hz}), 0.86(\mathrm{~s}, 3 \mathrm{H}), 0.95(\mathrm{~d}, 3 \mathrm{H}, J=5.0 \mathrm{~Hz}), 1.98$ (s, $3 \mathrm{H}), 2.06(\mathrm{~s}, 3 \mathrm{H}), 2.25(\mathrm{~d}, 2 \mathrm{H}, J=7.6 \mathrm{~Hz}), 2.55(\mathrm{t}, J=11.5 \mathrm{~Hz}), 3.30(\mathrm{dd}, 1 \mathrm{H}, J=2.4$ and 11.7 $\mathrm{Hz}), 4.57(\mathrm{~m}, 1 \mathrm{H}), 5.08(\mathrm{~m}, 1 \mathrm{H}), 5,29(\mathrm{~d}, 1 \mathrm{H}, J=4.1 \mathrm{~Hz}) ;{ }^{13} \mathrm{C} \operatorname{NMR} \delta 12.42(\mathrm{q}), 13.05(\mathrm{q}), 18.61$ (q), 19.29 (q), 20.64 (t), 21.47 (2q), 23.84 (t), 27.69 (t), 30.61 (d), 31.32 (d), 31.58 (t), 31.90 (d), $32.16(\mathrm{t}), 34.76(\mathrm{t}), 36.53(\mathrm{~s}), 36.90(\mathrm{t}), 38.04(\mathrm{t}), 39.47(\mathrm{t}), 42.72(\mathrm{~s}), 49.86(\mathrm{~d}), 54.63(\mathrm{~d}), 55.63$ (d), 58.35 (t), 59.64 (d), 73.80 (d), 73.88 (d), 116.97 (s), 122.10 (d), 139.78 (s), 170.56 (s), 171.04 (s). MS m/z (r.i.) 524 (1), 509 (7), 464 (26), 449 (19), 151 (100), 123 (100); HRMS calculated for $\mathrm{C}_{32} \mathrm{H}_{48} \mathrm{~N}_{2} \mathrm{O}_{4}\left([\mathrm{M}]^{+}\right)$524.3614, found 524.3614.

$(3 \beta, 20 S)-20-[(2 R, 5 S)-1-C y a n o-5-m e t h y l p i p e r i d i n y l] p r e g n a-5,16-d i e n-3-y l$ acetate (16). Compound $12(0.1 \mathrm{~g}, 0.18 \mathrm{mmol})$ was dissolved in s-collidine $(2 \mathrm{ml})$ and heated at reflux temperature for 16 hours. After cooling, the reaction mixture was diluted with EA, washed with aqueous $\mathrm{HCl}(10 \%)$ and water, and dried. Evaporation of the solvent in vacuo yielded $16(0.083 \mathrm{~g}, 98 \%)$ as a white crystalline product. M.p. $170-175^{\circ} \mathrm{C}\left(173^{\circ} \mathrm{C}[\mathrm{Schramm}, 1970 \# 3725]\right) ;{ }^{1} \mathrm{H}$ NMR $\delta 0.81(\mathrm{~d}, 1 \mathrm{H}, J=$ $5.8 \mathrm{~Hz}), 0.82(\mathrm{~s}, 3 \mathrm{H}), 0.99(\mathrm{~s}, 3 \mathrm{H}), 0.99(\mathrm{~d}, 3 \mathrm{H}, J=6.8 \mathrm{~Hz}), 1.97(\mathrm{~s}, 3 \mathrm{H}), 2.26$ (d, 2H, J= 7.4 Hz), $2.55(\mathrm{t}, 1 \mathrm{H}, J=11.9 \mathrm{~Hz}), 2.77(\mathrm{~m}, 1 \mathrm{H}), 3.30(\mathrm{~m}, 1 \mathrm{H}), 4.55(\mathrm{~m}, 1 \mathrm{H}), 5.32(\mathrm{~d}, 1 \mathrm{H}, J=4.3 \mathrm{~Hz}), 5.40$ $(\mathrm{m}, 1 \mathrm{H}) ;{ }^{13} \mathrm{C} \operatorname{NMR} \delta 15.67(\mathrm{q}), 17.03(\mathrm{q}), 18.43(\mathrm{q}), 19.17(\mathrm{q}), 20.60(\mathrm{t}), 21.41(\mathrm{q}), 25.30(\mathrm{t})$, $27.68(\mathrm{t}), 29.91(\mathrm{~d}), 30.33(\mathrm{~d}), 31.09(\mathrm{t}), 31.43(\mathrm{t}), 32.59(\mathrm{t}), 34.92(\mathrm{t}), 35.24(\mathrm{~d}), 36.73(\mathrm{~s}), 36.85$ $(\mathrm{t}), 38.07$ (t), 46.83 (s), 50.37 (d), 57.77 (d), 58.47 (t), 61.14 (d), 73.84 (d), 117.08 (s), 122.37 (d), 124.90 (d), 139.88 (s), $156.02(\mathrm{~s}), 170.48$ (s).

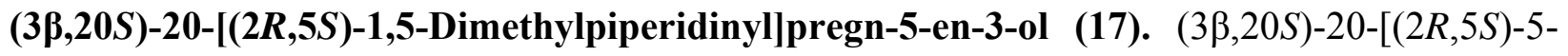
Methylpiperidinyl]pregn-5-en-3-ol was prepared as described in the literature, the NMR data were in accordance with the literature data. ${ }^{97-100} \mathrm{~A}$ suspension of this compound $(0.07 \mathrm{~g}$, $0.175 \mathrm{mmol}), \mathrm{Na}_{2} \mathrm{CO}_{3}(0.035 \mathrm{~g})$, and $\mathrm{MeI}(0.07 \mathrm{ml}, 1.12 \mathrm{mmol})$ in water was heated at reflux temperature for 7 hours. After cooling, the white precipitate was filtered and washed with water. 
The crude material was suspended in methanolic $\mathrm{KOH}(3.5 \mathrm{M}, 5 \mathrm{ml})$ and heated under reflux for 3 hours. After cooling, the alkaline mixture was concentrated and water was added. The mixture was extracted three times with ether $(5 \mathrm{ml})$ and dried. Evaporation of the solvent in vacuo yielded an amorphous material (0.065 g) which was flash chromatographed $\left(\mathrm{CHCl}_{3} / \mathrm{MeOH} 9 / 1\right)$ yielding 17 (0.055 g, 76\%) as a white solid. M.p. 296-301 ${ }^{\circ} \mathrm{C} ;{ }^{1} \mathrm{H} \mathrm{NMR}\left(\mathrm{CDCl}_{3}+\mathrm{CD}_{3} \mathrm{OD}\right) \delta 0.51$ $(\mathrm{s}, 3 \mathrm{H}), 0.73(\mathrm{~d}, 3 \mathrm{H}, J=6.6 \mathrm{~Hz}), 0.77(\mathrm{~s}, 3 \mathrm{H}), 0.88(\mathrm{~d}, 3 \mathrm{H}, J=6.7 \mathrm{~Hz}), 2.03(\mathrm{~m}, 2 \mathrm{H}), 2.34(\mathrm{t}, 1 \mathrm{H}$, $J=12.0 \mathrm{~Hz}), 2.51(\mathrm{~s}, 3 \mathrm{H}), 3.20(\mathrm{~m}, 1 \mathrm{H}), 5.11(\mathrm{~d}, 1 \mathrm{H}, J=4.3 \mathrm{~Hz}) ;{ }^{13} \mathrm{C} \mathrm{NMR}\left(\mathrm{CDCl}_{3}+\mathrm{CD}_{3} \mathrm{OD}\right) \delta$ 11.44 (q), 12.25 (q), 17.94 (q), 18.98 (q), $20.72(\mathrm{t}), 22.38(\mathrm{t}), 23.79$ (t), $27.18(\mathrm{t}), 29.22(\mathrm{~d}), 30.79$ $(\mathrm{t}), 31.04(\mathrm{t}), 31.45(\mathrm{t}), 31.61(\mathrm{~d}), 34.21(\mathrm{~d}), 36.17(\mathrm{~s}), 36.95(\mathrm{t}), 39.45(\mathrm{t}), 40.35(\mathrm{q}), 41.47(\mathrm{t})$, 42.52 (s), 49.69 (d), 52.15 (d), 56.08 (d), 63.46 (t), 69.24 (d), 70.84 (d), 120.87 (d), 140.70 (s); MS m/z (r.i.) 412 (2), 112 (100); HRMS calculated for $\mathrm{C}_{28} \mathrm{H}_{46} \mathrm{NO}\left([\mathrm{M}-\mathrm{H}]^{+}\right.$) 412.3579, found 412.3579 .

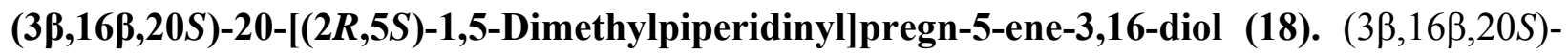
20 -[(2R,5S)-5-Methylpiperidinyl]pregn-5-ene-3,16-diol was prepared as described in the literature, the NMR and mass data were in accordance with the literature data ${ }^{101}$. A suspension of this compound $(0.04 \mathrm{~g}, 0.096 \mathrm{mmol}), \mathrm{Na}_{2} \mathrm{CO}_{3}(0.02 \mathrm{~g})$, and $\mathrm{MeI}(0.04 \mathrm{ml}, 0.64 \mathrm{mmol})$ in water was heated at reflux temperature for 7 hours. After cooling, the white precipitate was filtered and washed with water. Drying on air gave the ammonium salt $(0.04 \mathrm{~g}, 99 \%)$ as a white solid. ${ }^{1} \mathrm{H}$ $\operatorname{NMR}\left(\mathrm{CDCl}_{3}+\mathrm{CD}_{3} \mathrm{OD}\right) \delta 0.52(\mathrm{~s}, 3 \mathrm{H}), 0.52(\mathrm{~d}, 3 \mathrm{H}, J=6.7 \mathrm{~Hz}), 0.58(\mathrm{~s}, 3 \mathrm{H}), 0.66(\mathrm{~d}, 1 \mathrm{H}, J=6.8$ $\mathrm{Hz}), 2.64(\mathrm{~s}, 3 \mathrm{H}), 2.82(\mathrm{~s}, 3 \mathrm{H}), 3.83(\mathrm{~m}, 1 \mathrm{H}), 4.89(\mathrm{~d}, 1 \mathrm{H}, J=4.6 \mathrm{~Hz})$; ${ }^{13} \mathrm{C} \mathrm{NMR}$ $\left(\mathrm{CDCl}_{3}+\mathrm{CD}_{3} \mathrm{OD}\right) \delta 11.83(\mathrm{q}), 14.26(\mathrm{q}), 16.91(\mathrm{q}), 18.25(\mathrm{q}), 20.02(\mathrm{t}), 20.39(\mathrm{t}), 26.06(\mathrm{~d}), 28.27$ (d), 30.26 (d), 30.43 (s), 30.89 (2t), 35.70 (s), 36.40 (2t), 39.41 (t), 40.97 (2t), 42.05 (q), 44.30 (d), 46.21 (q), 49.27 (d), 53.56 (q), 53.84 (d), 57.98 (d), 68.93 (d), 70.36 (t), 72.80 (t), 73.63 (d), 120.27 (d), 140.25 (s).

A suspension of this salt in $3.5 \mathrm{M}$ methanolic $\mathrm{KOH}(3 \mathrm{ml}, 10.5 \mathrm{mmol})$ was heated at reflux temperature for 3 hours. After cooling, the reaction mixture was filtered and washed with water. Flash chromatography $\left(\mathrm{CHCl}_{3} / \mathrm{MeOH} 1 / 1\right)$ gave $18(0.013 \mathrm{~g}, 32 \%)$ as a white solid. M.p. 199$202^{\circ} \mathrm{C}\left(196.5-198.5^{\circ} \mathrm{C}^{99}\right) ;{ }^{1} \mathrm{H}$ NMR $\delta 0.76(\mathrm{~s}, 3 \mathrm{H}), 0.85$ (d, 3H, J= 7.0 Hz), $0.92(\mathrm{~d}, 6 \mathrm{H}, J=6.6$ Hz), 0.96 (s, 3H), 2.32 (s, 3H), 3.46 (m, 1H), 3.94 (m, 1H), 4.43 (q, 1H, J=7.2 Hz), 5.29 (d, 1H, $J=4.9 \mathrm{~Hz}) ;{ }^{13} \mathrm{C}$ NMR $\delta 14.75(\mathrm{q}), 16.27$ (q), 18.34 (q), 19.44 (q), 20.74 (t), 27.37 (t), 30.41 (d), $30.98(\mathrm{~d}), 31.61(\mathrm{t}), 32.04(\mathrm{~s}), 32.11(\mathrm{t}), 33.46(\mathrm{t}), 35.45(\mathrm{~d}), 36.67(\mathrm{t}), 37.21(\mathrm{t}), 39.67(\mathrm{t}), 40.92$ $(\mathrm{s}), 42.27(\mathrm{t}), 45.11(\mathrm{q}), 50.14(\mathrm{~d}), 55.55$ (d), 64.31 (d), 66.08 (t), 71.68 (d), 81.63 (d), $84.11(\mathrm{~d})$, 121.40 (d), 140.82 (s). The NMR spectral data were in accordance with the literature data. ${ }^{99,102}$

(3ß,20S)-20-[(2R,5S)-1,1,5-Trimethylpiperidiniumyl]pregna-5,16-dien-3-ol iodide (20). $(3 \beta, 20 S)-20-[(2 R, 5 S)-5-M e t h y l p i p e r i d i n y l] p r e g n a-5,16-d i e n-3-o l$ was prepared as described in the literature, the NMR data are identical with those obtained from the reduction with Red-A1.

A suspension of this compound $(0.048 \mathrm{~g}, 0.13 \mathrm{mmol}), \mathrm{Na}_{2} \mathrm{CO}_{3}(0.025 \mathrm{~g})$, and $\mathrm{MeI}(0.05 \mathrm{ml}$, $0.8 \mathrm{mmol})$ in water $(4 \mathrm{ml})$ was heated under reflux for 7 hours. After cooling, the white precipitate was filtered and washed with water. Drying on air gave $20(0.065 \mathrm{~g}, 97 \%)$ as a rather 
unstable compound through which further purification failed. ${ }^{1} \mathrm{H}$ NMR (DMSO) $\delta 0.83(\mathrm{~s}, 6 \mathrm{H})$, 0.83 (d, 3H, J=6.8 Hz), 0.97 (s, 3H), 0.99 (d, 3H, J= $7.0 \mathrm{~Hz}), 2.99$ (s, 3H), 3.14 (s, 3H), 4.62 (d, $1 \mathrm{H}, J=4.4 \mathrm{~Hz}), 5.27(\mathrm{~d}, 1 \mathrm{H}), 5.50(\mathrm{~m}, 1 \mathrm{H})$.

$(3 \beta, 25 S)-26-(D i m e t h y l a m i n o) c h o l e s t a-5,16,20(22)-t r i e n-3-o l ~(21)$ and $(3 \beta, 20 R)-20-[(2 R, 5 S)-$ 1,5-dimethylpiperidinyl]pregna-5,16-dien-3-ol (19). To a solution of isopropylamine $(0.85 \mathrm{ml}$, $10 \mathrm{mmol})$ in THF $(2.9 \mathrm{ml})$ was added $1.6 \mathrm{M} \mathrm{n}$-BuLi $(6.25 \mathrm{ml}, 10 \mathrm{mmol})$ in hexane at $-20^{\circ} \mathrm{C}$. The reaction mixture was cooled to $-60^{\circ} \mathrm{C}$ and stirring was continued for 30 minutes. To a suspension of $20(0.29 \mathrm{~g}, 0.49 \mathrm{mmol})$ in THF $(3 \mathrm{ml})$ was added freshly prepared $1 \mathrm{M} \mathrm{LDA}(1.6 \mathrm{ml}$, $1.60 \mathrm{mmol}$ ) at $-78^{\circ} \mathrm{C}$. The reaction mixture was allowed to warm to room temperature, stirred for 4 hours, and then quenched with an aqueous saturated $\mathrm{NH}_{4} \mathrm{Cl}$ solution. The reaction mixture was extracted three times with $\mathrm{CH}_{2} \mathrm{Cl}_{2}(15 \mathrm{ml})$. The combined organic layers were washed with saturated brine, dried, and evaporated in vacuo. The residue was purified by flash chromatography $\left(\mathrm{CHCl}_{3} / \mathrm{MeOH} 9 / 1\right)$ to afford $21(0.070 \mathrm{~g}, 32 \%)$ and $19(0.055 \mathrm{~g}, 26 \%)$, both as white solids.

21. M.p. $164-165^{\circ} \mathrm{C}(\mathrm{MeOH})$; IR $v_{\max }$ (neat): $3224,1457,1375,1063 \mathrm{~cm}^{-1} .{ }^{1} \mathrm{H}$ NMR $\delta 0.90(\mathrm{~d}$, $3 \mathrm{H}, J=6.5 \mathrm{~Hz}), 0.94(\mathrm{~s}, 3 \mathrm{H}), 1.00(\mathrm{~s}, 3 \mathrm{H}), 1.62(\mathrm{~s}, 3 \mathrm{H}), 2.19(\mathrm{~s}, 6 \mathrm{H}), 3.50(\mathrm{~m}, 1 \mathrm{H}), 5.34-5.59(\mathrm{~m}$, $3 \mathrm{H}) ;{ }^{13} \mathrm{C} \mathrm{NMR}\left(\mathrm{CDCl}_{3}\right) 15.3(\mathrm{q}), 16.2(\mathrm{q}), 18.1(\mathrm{q}), 19.3(\mathrm{q}), 21.0(\mathrm{t}), 25.8(\mathrm{t}), 30.3(\mathrm{~d}), 30.6(\mathrm{~d})$, $30.9(\mathrm{t}), 31.5(\mathrm{t}), 31.6(\mathrm{t}), 35.0(\mathrm{t}), 36.1(\mathrm{t}), 36.6(\mathrm{~s}), 37.1(\mathrm{t}), 42.3(\mathrm{t}), 45.8(2 \mathrm{q}), 46.7(\mathrm{~s}), 50.3(\mathrm{~d})$, 57.6 (d), 67.0 (t), 71.7 (d), 121.5 (d), 124.8 (d), 126.6 (d), 130.5 (s), 141.0 (s), 156.4 (s); MS m/z (r.i.) 410 (2), 397 (4), 382 (1), 204 (2), 150 (8), 112 (100); HRMS calculated for $\mathrm{C}_{29} \mathrm{H}_{46} \mathrm{NO}$ ([M$\left.\mathrm{H}]^{+}\right) 425.3658$, found 425.3658 .

19. M.p. $148-151^{\circ} \mathrm{C}$; IR $v_{\max }$ (neat): $3382,1455,1376 \mathrm{~cm}^{-1} ;{ }^{1} \mathrm{H}$ NMR $\left(\mathrm{CDCl}_{3}+\mathrm{CD}_{3} \mathrm{OD}\right) \delta$ $0.73(\mathrm{~s}, 3 \mathrm{H}), 0.81(\mathrm{~d}, 3 \mathrm{H}, J=6.4 \mathrm{~Hz}), 0.90(\mathrm{~s}, 3 \mathrm{H}), 1.04$ (d, 3H, J=6.9 Hz), $2.59(\mathrm{~s}, 3 \mathrm{H}), 3.25(\mathrm{~m}$, $1 \mathrm{H}), 5.29(\mathrm{~m}, 1 \mathrm{H}), 5.45(\mathrm{~m}, 1 \mathrm{H}) ;{ }^{13} \mathrm{C} \mathrm{NMR}\left(\mathrm{CDCl}_{3}\right) 12.7(\mathrm{q}), 17.0(\mathrm{q}), 19.0(\mathrm{q}), 19.3(\mathrm{q}), 20.5(\mathrm{t})$, $23.6(\mathrm{t}), 30.2(\mathrm{~d}), 31.0(\mathrm{t}), 31.4(\mathrm{t}), 31.5(\mathrm{t}), 32.2(\mathrm{t}), 32.5(\mathrm{~d}), 34.5(\mathrm{t}), 36.6(\mathrm{t}), 37.1(\mathrm{~s}), 41.8(\mathrm{q})$, $42.2(\mathrm{t}), 46.3(\mathrm{~s}), 50.4(\mathrm{~d}), 58.6(\mathrm{~d}), 65.3(\mathrm{t}), 66.9$ (d), 71.5 (d), 121.3 (d), 126.5 (d), 141.0 (s), 155.9 (s); MS m/z (r.i.) 425 (8), 410 (7), 124 (14), 112 (100), 98 (31), 58 (71); HRMS calculated for $\mathrm{C}_{28} \mathrm{H}_{44} \mathrm{NO}\left([\mathrm{M}-\mathrm{H}]^{+}\right) 410.3421$, found 410.3423 .

$(3 \beta, 16 \beta, 20 S)-20-[(2 R, 5 S)-1-C h l o r o-5-m e t h y l p i p e r i d i n y l] p r e g n-5-e n e-3,16-d i o l \quad(23) . \quad T h i s$ compound was prepared as described in the literature, the NMR and mass data were in accordance with literature data. ${ }^{100}$

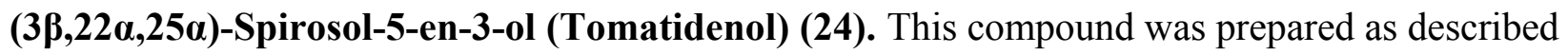
in the literature, M.p. $236-238^{\circ} \mathrm{C}\left(234-238^{\circ} \mathrm{C}\right)^{103}$

Method B. To a solution of $23(150.2 \mathrm{mg}, 0.33 \mathrm{mmol})$ in dry $\mathrm{CH}_{2} \mathrm{Cl}_{2}(3 \mathrm{ml})$ and dry $\mathrm{Et}_{2} \mathrm{O}(2 \mathrm{ml})$ was added DBU $(21 \mu \mathrm{l}, 0.14 \mathrm{mmol})$ at $-10^{\circ} \mathrm{C}$. After 2 hours, the reaction mixture was allowed to warm to room temperature, evaporated in vacuo, and crystallized from acetone to yield 24 $(100.8 \mathrm{mg}, 73 \%)$ as a white solid. M.p. $235-238^{\circ} \mathrm{C}\left(234-238^{\circ} \mathrm{C}^{103}\right)$. The NMR and mass data are identical to those mentioned in the literature. ${ }^{104}$ 


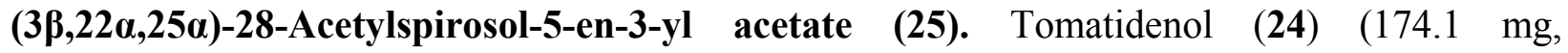
$0.42 \mathrm{mmol})$ was dissolved in a mixture of $\mathrm{Ac}_{2} \mathrm{O}(2 \mathrm{ml})$ and pyridine $(10 \mathrm{ml})$. After 24 hours, the reaction mixture was poured into ice-water. The suspension was filtered, and the filter cake was washed with water and recrystallized from acetone $/ \mathrm{H}_{2} \mathrm{O}$ to yield $\mathbf{2 5}(205.5 \mathrm{mg}, 98 \%)$ as a white solid. M.p. $161-163^{\circ} \mathrm{C}\left(163-165^{\circ} \mathrm{C}^{103}\right) ;{ }^{1} \mathrm{H}$ NMR $\delta 0.81$ (s, 3H), 0.84 (d, 3H, J=5.4 Hz), 1.00 (s, $3 \mathrm{H}), 1.19$ (d, 3H, J=6.9 Hz), 2.01 (s, 3H), 2.08 (s, 3H), 4.17 (q, 1H, J=6.6 Hz), 4.57 (m, 1H), 5.35 (d, $1 \mathrm{H}, J=4.4 \mathrm{~Hz}) ;{ }^{13} \mathrm{C}$ NMR $\delta 16.00$ (q), 17.78 (q), 19.02 (q), 19.34 (q), 20.70 (q), 21.46 $(\mathrm{t}), 24.75(\mathrm{q}), 27.73(\mathrm{t}), 28.13(\mathrm{t}), 28.36(\mathrm{t}), 31.50(\mathrm{~d}), 31.73(\mathrm{~d}), 32.03(\mathrm{t}), 32.75(\mathrm{t}), 36.71(\mathrm{~s})$, $36.96(\mathrm{t}), 38.09(\mathrm{t}), 38.52(\mathrm{~d}), 39.43(\mathrm{t}), 41.13(\mathrm{~s}), 50.00(\mathrm{~d}), 52.12(\mathrm{t}),, 56.40(\mathrm{~d}), 64.47$ (d), 73.89 (d), 78.84 (d), 101.03 (s), 122.29 (d), 139.81 (s), 170.41 (s), 170.59 (s). MS m/z (r.i.) 497 (72, M), 482 (100), 454 (15), 428 (37), 155 (31), 114 (15), 43 (9); HRMS calculated for $\mathrm{C}_{31} \mathrm{H}_{47} \mathrm{NO}_{4}$ 497.3505, found 497.3508.

(3ß,25S)-26-(Acetylamino)furosta-5,20(22)-dien-3-yl acetate (26). This compound was prepared from $\mathbf{2 5}$ as described in the literature, the NMR and mass data were in accordance with literature data. $^{91}$

(3ß)-3-Acetoxypregna-5,16-dien-20-one (dehydropregnenolone acetate, DPA) (6). This compound was prepared as described in the literature, the NMR data were in accordance with literature data. ${ }^{105}$

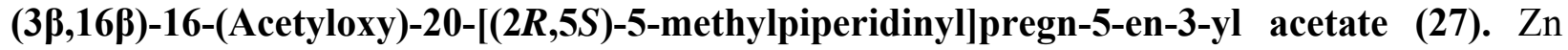
powder was activated as follows ${ }^{61}$ : To a vigorously stirred suspension of $\mathrm{Zn}$ (2 g, $\left.16 \mathrm{mmol}\right)$ in HOAc $(10 \mathrm{ml})$ was added a solution of $\mathrm{HCl}(2 \mathrm{M}, 10 \mathrm{ml})$, followed by an aqueous solution of $\mathrm{CuSO}_{4}(5 \%, 0.4 \mathrm{ml})$. After about 1 minute, the reaction mixture was decanted and the $\mathrm{Zn}$ washed several times with HOAc.

To a suspension of freshly activated $\mathrm{Zn}(210.7 \mathrm{mg})$ in HOAc $(1.3 \mathrm{ml})$ and $\mathrm{H}_{2} \mathrm{O}(3.0 \mathrm{ml})$ was added 15 (107.6 mg, $0.21 \mathrm{mmol})$ and the reaction mixture was heated at reflux temperature. After 2 hours, the reaction mixture was filtered through Hyflow and evaporated in vacuo. The residue was dissolved in $\mathrm{CHCl}_{3}$, washed with aqueous $\mathrm{NaOH}(0.05 \mathrm{M})$ and brine, dried, and evaporated in vacuo to obtain a white amorphous solid. Purification by column chromatography with $\mathrm{CHCl}_{3} / \mathrm{MeOH}$ 9/1 followed by crystallization from EtOAc gave $27(92.0 \mathrm{mg}, 90 \%)$ as a white solid. M.p. $170-173^{\circ} \mathrm{C}\left(172-173^{\circ} \mathrm{C}^{100}\right) ;{ }^{1} \mathrm{H}$ NMR $\left(\mathrm{CDCl}_{3}+\mathrm{CD}_{3} \mathrm{OD}\right) \delta 0.77(\mathrm{~d}, 3 \mathrm{H}, J=6.5$ $\mathrm{Hz}), 0.83$ (s, 3H), 0.91 (d, 3H, J=5.6 Hz), 0.93 (s,3H), $1.93(\mathrm{~s}, 3 \mathrm{H}), 2.02(\mathrm{~s}, 3 \mathrm{H}), 3.27(\mathrm{dd}, 1 \mathrm{H}$, $J=2.7$ and $11.7 \mathrm{~Hz}), 3.50(\mathrm{~s}, 1 \mathrm{H}, \mathrm{NH}), 4.48(\mathrm{~m}, 1 \mathrm{H}), 5.04(\mathrm{td}, 1 \mathrm{H}, J=3.8$ and $7.6 \mathrm{~Hz}), 5.25(\mathrm{~d}$, $1 \mathrm{H}, J=4.4 \mathrm{~Hz}) ;{ }^{13} \mathrm{C}$ NMR $\delta 12.23(\mathrm{q}), 12.89(\mathrm{q}), 18.42$ (q), $19.14(\mathrm{q}), 20.53(\mathrm{t}), 21.25(2 \mathrm{q}), 23.73$ $(\mathrm{t}), 27.56(\mathrm{t}), 30.50(\mathrm{~d}), 31.23(\mathrm{~d}), 31.46(\mathrm{t}), 31.83(\mathrm{~d}), 32.00(\mathrm{t}), 34.63(\mathrm{t}), 36.43(\mathrm{~s}), 36.77(\mathrm{t})$, $37.89(\mathrm{t}), 39.34(\mathrm{t}), 42.62(\mathrm{~s}), 49.74(\mathrm{~d}), 54.50$ (d), 10.46 (d), $58.14(\mathrm{t}), 59.57$ (d), 73.99 (d), 74.06 (d), $122.04(\mathrm{~d}), 139.63$ (s), 171.02 (s), 171.26 (s). The NMR data are in accordance with literature data. ${ }^{100}$ 


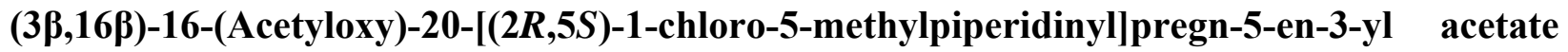
(28). This compound was prepared from 27 as described for the synthesis of 23 , the NMR and mass data were in accordance with literature data. ${ }^{100}$

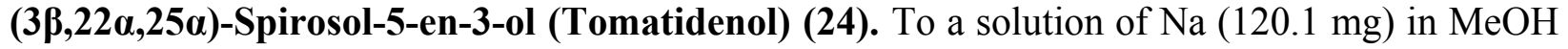
$(60 \mathrm{ml})$ was added a solution of $27(34.5 \mathrm{mg}, 0.65 \mu \mathrm{mol})$ in $\mathrm{MeOH}(5 \mathrm{ml})$. After reflux for 1 hour, the reaction mixture was concentrated in vacuo, and the remaining residue was taken up in $\mathrm{H}_{2} \mathrm{O}(10 \mathrm{ml})$. The mixture was extracted three times with $\mathrm{CHCl}_{3}(25 \mathrm{ml})$, dried, and evaporated in vacuo to yield $4(27.5 \mathrm{mg}, 85 \%)$ as a white solid. M.p. $234-238^{\circ} \mathrm{C}\left(134-138^{\circ} \mathrm{C}^{103}\right)$. The NMR and mass data are identical with those obtained in method $\mathrm{A}$ as previously described for the synthesis of tomatidenol (28).

(3S,6aS,6bS,7aS,12S,14aR,15aR,15bS,17aS,17bR)-9-imino-12,15,15b,17b-tetramethyl-2,3,4, 6,6a,6b,7,7a,11,12,13,14,14a,15,15a,15b,16,17,17a,17b-icosahydro-1H-

naphtho[2', $\left.1^{\prime}: 4,5\right]$ indeno $[1,2-f]$ pyrido[1,2-c][1,3]oxazepin-3-ol (29). To a solution of $\mathrm{Na}$ $(250.3 \mathrm{mg})$ in $\mathrm{MeOH}(120 \mathrm{ml})$ was added a solution of $\mathbf{1 5}(121.3 \mathrm{mg}, 0.23 \mathrm{mmol})$ in $\mathrm{MeOH}$ $(10 \mathrm{ml})$. After reflux for 1 hour, the reaction mixture was concentrated in vacuo, and the remaining residue was taken up in $\mathrm{H}_{2} \mathrm{O}(10 \mathrm{ml})$. The mixture was extracted three times with $\mathrm{CHCl}_{3}(25 \mathrm{ml})$, dried, and evaporated in vacuo to yield $29(101.3 \mathrm{~g}, 81 \%)$ as a brown solid. ${ }^{1} \mathrm{H}$ $\operatorname{NMR}\left(\mathrm{CDCl}_{3}\right) \delta 0.77(\mathrm{~d}, 3 \mathrm{H}, J=6.1 \mathrm{~Hz}), 0.78(\mathrm{~s}, 3 \mathrm{H}), 0.95(\mathrm{~s}, 3 \mathrm{H}), 0.95(\mathrm{~d}, 3 \mathrm{H}, J=6.5 \mathrm{~Hz}), 4.63$ $(\mathrm{q}, 1 \mathrm{H}, J=7.6 \mathrm{~Hz}), 5.27$ (d, $1 \mathrm{H}, J=4.9 \mathrm{~Hz}) ;{ }^{13} \mathrm{C} \mathrm{NMR} \delta 13.02$ (q), 17.87 (q), 18.92 (q), 19.35 (q), $20.82(\mathrm{t}), 27.62(\mathrm{~d}), 30.15(\mathrm{t}), 30.96(\mathrm{~d}), 31.52(\mathrm{t}), 31.89(\mathrm{t}), 33.21(\mathrm{t}), 34.44(\mathrm{t}), 34.81(\mathrm{~d}), 36.45$ $(\mathrm{s}), 37.12(\mathrm{t}), 40.22(\mathrm{t}), 42.18(\mathrm{t}), 42.60(\mathrm{~s}), 49.83(\mathrm{~d}), 53.01(\mathrm{~d}), 57.55(\mathrm{t}), 57.86(\mathrm{~d}), 65.92(\mathrm{~d})$, 71.58 (d), 80.56 (d), 121.19 (d), 140.83 (s), 163.53 (s); MS m/z (r.i.) 440 (15, M), 422 (7), 397 (27), 393 (15), 322 (34), 204 (11), 150 (47), 123 (34), 98 (100); HRMS calculated for $\mathrm{C}_{28} \mathrm{H}_{44} \mathrm{~N}_{2} \mathrm{O}_{2} 440.3403$, found 440.3400 .

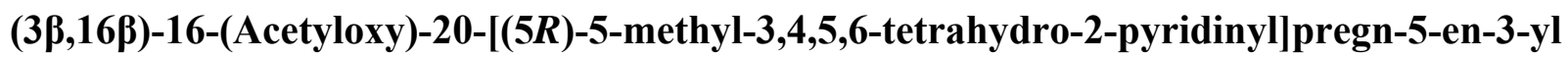

acetate (33). This compound was prepared from solasodine as described in the literature ${ }^{85,100}$, the NMR and mass data were in accordance with literature data. ${ }^{100}$

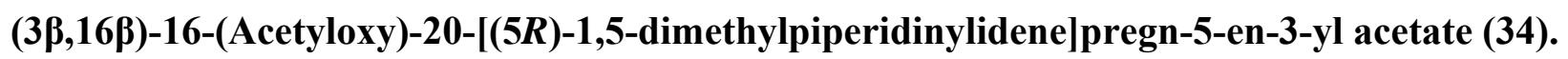
To a solution of $33(1.07 \mathrm{~g}, 2.15 \mathrm{mmol})$ in benzene $(50 \mathrm{ml})$ and acetone $(100 \mathrm{ml})$ was added MeI $(10 \mathrm{ml}, \mathrm{mmol})$. After 3 hours reflux, the mixture was concentrated in vacuo and the remaining residue was dissolved in acetone. Precipitation with $n$-hexane and air-drying gave $(3 \beta, 16 \beta)-3,16-$ Bis(acetyloxy)-20-[(5R)-1,5-dimethyl-3,4,5,6-tetrahydro-2-pyridiniumyl]pregn-5-ene iodide $(1.12 \mathrm{~g}, 82 \%)$ as a white solid. M.p. $266-268^{\circ} \mathrm{C}\left(268-270^{\circ} \mathrm{C}^{85}\right) ;{ }^{1} \mathrm{H}$ NMR $\delta 0.94$ (s, 3H), 1.00 (s, $3 \mathrm{H}), 1.08(\mathrm{~d}, 3 \mathrm{H}, J=4.5 \mathrm{~Hz}), 1.59(\mathrm{~d}, 3 \mathrm{H}, J=6.8 \mathrm{~Hz}), 2.00(\mathrm{~s}, 3 \mathrm{H}), 2.06(\mathrm{~s}, 3 \mathrm{H}), 3.32(\mathrm{q}, 1 \mathrm{H}, J=$ $5.4 \mathrm{~Hz}), 3.78(\mathrm{~s}, 3 \mathrm{H}), 4.33(\mathrm{~m}, 1 \mathrm{H}), 4.56(\mathrm{~m}, 1 \mathrm{H}), 5.13(\mathrm{~m}, 1 \mathrm{H}), 5.32(\mathrm{~d}, 1 \mathrm{H}, J=4.4 \mathrm{~Hz}) ;{ }^{13} \mathrm{C}$ NMR $\delta 13.30$ (q), 17.88 (q), 18.01 (q), 19.29 (q), 20.70 (t), 21.45 (q), 21.87 (q), 24.47 (t), 27.10 $(\mathrm{d}), 27.64(\mathrm{t}), 29.05(\mathrm{t}), 31.20(\mathrm{~d}), 31.51(\mathrm{t}), 34.96(\mathrm{t}), 36.51(\mathrm{~s}), 36.83(\mathrm{t}), 37.07(\mathrm{~d}), 37.99(\mathrm{t})$, $39.66(\mathrm{t}), 43.47(\mathrm{~s}), 45.52$ (q), 49.10 (d), $53.61(\mathrm{~d}), 54.89$ (d), $62.87(\mathrm{t}), 73.68$ (d), $74.54(\mathrm{~d})$, 121.76 (d), 139.84 (s), 169.85 (s), 170.57 (s), 192.26 (s). 
To a solution of this compound $(695.3 \mathrm{mg}, 1.09 \mathrm{mmol})$ in acetone $(150 \mathrm{ml})$ was added an aqueous solution of $\mathrm{NaHCO}_{3}(100 \mathrm{ml}, 1 \mathrm{M})$. The resulting white suspension was filtered, washed with water, and air-dried yielding 34 (536.8 mg, 97\%) as a white solid. M.p. 194-196 ${ }^{\circ} \mathrm{C}(194-$ $\left.197^{\circ} \mathrm{C}^{85}\right) ;{ }^{1} \mathrm{H}$ NMR $\left(\mathrm{C}_{6} \mathrm{D}_{6}\right) \delta 0.93(\mathrm{~s}, 3 \mathrm{H}), 0.95(\mathrm{~s}, 3 \mathrm{H}), 1.21(\mathrm{~d}, 3 \mathrm{H}, J=6.8 \mathrm{~Hz}), 1.80(\mathrm{~s}, 3 \mathrm{H}), 1.84$ (s, 3H), 1.93 (br s), 2.53 (s, 3H), 4.54 (d, 1H, J=2.8 Hz), 4.88 (quintet, 1H, J=5.3 Hz), 5.35 (d, $1 \mathrm{H}, J=4.4 \mathrm{~Hz}), 5.53(\mathrm{q}, 1 \mathrm{H}, J=6.2 \mathrm{~Hz}) ;{ }^{13} \mathrm{C} \mathrm{NMR}\left(\mathrm{C}_{6} \mathrm{D}_{6}\right) \delta 12.62$ (q), $19.11(\mathrm{q}), 19.33(\mathrm{q}), 20.80$ (t), $20.80(2 \mathrm{q}), 21.60$ (q), 26.51 (d), $27.96(2 \mathrm{t}), 31.34$ (d), 31.68 (t), 34.52 (t), 36.48 (s), $36.90(\mathrm{t})$, 38.37 (2t), 39.21 (q), 39.76 (t), 42.09 (s), 49.88 (d), 54.22 (d), $58.96(\mathrm{~d}), 59.99$ (t), 73.58 (d), 74.22 (d), 95.80 (s), 122.49 (d), 139.48 (s), 150.06 (s), 168.96 (s), 169.35 (s); MS m/z (r.i.) 512 (33), 511 (67), 468 (40), 452 (100), 127 (54), 126 (83), 98 (70); HRMS calculated for $\mathrm{C}_{32} \mathrm{H}_{49} \mathrm{NO}_{4}$ 511.3662, found 511.3664. The NMR and mass spectra were compared to literature data of comparable compounds. $^{90}$

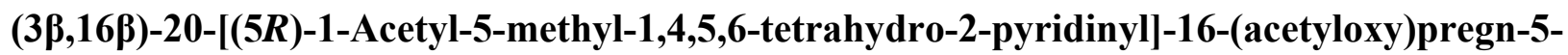
en-3-yl acetate (35). This compound was prepared from $\mathbf{3 3}$ as described in the literature, ${ }^{89}$ the NMR and mass data were in accordance with literature data. ${ }^{90}$

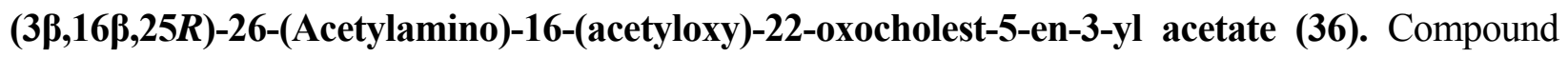
35 (1.09 g, $2.02 \mathrm{mmol})$ was added to a mixture of aqueous $\mathrm{HCl}(5 \mathrm{ml}, 5 \mathrm{M})$ and $\mathrm{HOAc}(20 \mathrm{ml})$. After 1.5 hours, the reaction mixture was diluted with water $(200 \mathrm{ml})$ and neutralized with solid $\mathrm{NaHCO}_{3}$. The mixture was extracted three times with $\mathrm{CHCl}_{3}(150 \mathrm{ml})$, dried, and evaporated in vacuo to obtain a yellow oil. Crystallization from acetone/hexane gave 36 (1.12 g, 99\%) as white crystals. M.p. $176-179^{\circ} \mathrm{C}\left(175-178^{\circ} \mathrm{C}^{89}\right) ;{ }^{1} \mathrm{H}$ NMR $\delta 0.84$ (s, 3H), 0.86 (d, 3H, J=7.5 Hz), 1.00 $(\mathrm{s}, 3 \mathrm{H}), 1.11(\mathrm{~d}, 3 \mathrm{H}, J=7.1 \mathrm{~Hz}), 1.93(\mathrm{~s}, 3 \mathrm{H}), 1.97(\mathrm{~s}, 3 \mathrm{H}), 2.00(\mathrm{~s}, 3 \mathrm{H}), 3.06(\mathrm{t}, 1 \mathrm{H}, J=5.9 \mathrm{~Hz})$, $4.57(\mathrm{~m}, 1 \mathrm{H}), 4.95(\mathrm{~m}, 1 \mathrm{H}), 5.33(\mathrm{~d}, 1 \mathrm{H}, J=4.4 \mathrm{~Hz}), 5.96(\mathrm{~m}, 1 \mathrm{H}, \mathrm{NH}) ;{ }^{13} \mathrm{C} \mathrm{NMR} \delta 13.18(\mathrm{q})$, $16.76(\mathrm{q}), 17.73$ (q), 19.24 (q), $20.65(\mathrm{t}), 21.12$ (q), 21.39 (q), 23.30 (q), 27.03 (t), $27.64(\mathrm{t})$, 31.19 (d), $31.54(\mathrm{t}), 32.80(\mathrm{~d}), 34.73(\mathrm{t}), 36.49(\mathrm{~s}), 36.89(\mathrm{t}), 37.97(\mathrm{t}), 38.04(\mathrm{t}), 39.32(\mathrm{t}), 41.84$ (s), 43.52 (d), 44.94 (t), 49.69 (d), 53.87 (d), 60.02 (d), 73.78 (d), 75.58 (d), 122.24 (d), 139.58 (s), 169.88 (s), 170.36 (s), 170.51 (s), 213.45 (s); MS m/z (r.i.) 107 (11), 497 (7), 437 (6), 422 (14), 252 (84), 114 (100), 43 (10); HRMS calculated for $\mathrm{C}_{33} \mathrm{H}_{51} \mathrm{NO}_{6}$ 107.3716, found 107.3720. The NMR and mass spectra were compared to literature data of comparable compounds. ${ }^{90}$

(25R)-26-(Acetylamino)-22-methoxyfurost-5-en-3-yl acetate (37). To a solution of 36 $(249.5 \mathrm{mg}, 0.44 \mathrm{mmol})$ in $\mathrm{MeOH}(10 \mathrm{ml})$ was added an aqueous solution of $\mathrm{K}_{2} \mathrm{CO}_{3}(2 \mathrm{ml}, 0.3$ $\mathrm{M})$. The reaction mixture was refluxed for 3 hours, cooled to room temperature, and then mixed with aqueous HOAc $(1.5 \mathrm{ml}, 20 \%)$. After 1 hour, the reaction mixture was neutralized by addition of aqueous $\mathrm{NaHCO}_{3}$, extracted three times with $\mathrm{CHCl}_{3}(25 \mathrm{ml})$, dried, and evaporated in vacuo. The remaining residue was crystallized from aqueous methanol to yield 37 (190.9 $\mathrm{mg}$, $82 \%$ ) as a white solid. M.p. $138-140^{\circ} \mathrm{C}\left(138-140 \mathrm{C}^{\mathrm{o} 91}\right) ;{ }^{1} \mathrm{H} \mathrm{NMR}\left(\mathrm{CDCl}_{3}+\mathrm{CD}_{3} \mathrm{OD}\right) \delta 0.71(\mathrm{~s}, 3 \mathrm{H})$, $0.81(\mathrm{~d}, 3 \mathrm{H}, J=6.4 \mathrm{~Hz}), 0.92(\mathrm{~d}, 3 \mathrm{H}, J=5.0 \mathrm{~Hz}), 0.94(\mathrm{~s}, 3 \mathrm{H}), 1.87(\mathrm{~s}, 3 \mathrm{H}), 3.30(\mathrm{~s}, 3 \mathrm{H}), 3.33(\mathrm{~m}$, $1 \mathrm{H}), 4.50$ (q, 1H, J=7.2 Hz), $5.23(\mathrm{~d}, 1 \mathrm{H}, J=3.8 \mathrm{~Hz}), 7.23(\mathrm{~m}, 1 \mathrm{H}, \mathrm{NH}) ;{ }^{13} \mathrm{C}$ NMR $\delta 15.17$ (q), 16.07 (q), 17.36 (q), 17.73 (q), 19.16 (q), 20.63 (t), 22.38 (q), 27.58 (t), 30.97 (d), 31.23 (t), 
$31.63(\mathrm{t}), 31.85(\mathrm{t}), 33.14(\mathrm{~d}), 35.36(\mathrm{t}), 36.46(\mathrm{~s}), 37.07(\mathrm{t}), 39.49(\mathrm{t}), 39.69(\mathrm{~d}), 40.44(\mathrm{~s}), 41.69$ (t), 44.74 (t), 49.51 (q), 49.90 (d), 56.21 (d), 62.25 (d), 71.00 (d), 81.00 (d), 110.41 (s), 120.96 (d), 140.82 (s), 171.55 (s), 171.64 (s) . The NMR spectra were compared to literature data of comparable compounds. ${ }^{91}$

$\boldsymbol{N}$-[(3ß,25R)-3,22-dihydroxyfurost-5-en-26-yl]acetamide (38). Method A. To a solution of 36 $(128.5 \mathrm{mg}, 0.23 \mathrm{mmol})$ in $\mathrm{EtOH}(10 \mathrm{ml})$ was added an aqueous solution of $\mathrm{K}_{2} \mathrm{CO}_{3}(1 \mathrm{ml}, 1.5 \mathrm{M})$. After heating for 3 hours at reflux temperature, the reaction mixture was poured onto ice, allowed to come to room temperature overnight, extracted three times with $\mathrm{CHCl}_{3}(50 \mathrm{ml})$, dried, and evaporated in vacuo to yield $\mathbf{3 8}$ as a colorless glass. Crystallization from acetone/hexane gave 38 (100.0 mg, 78\%) as a white solid. M.p. $120-122^{\circ} \mathrm{C}\left(119-122^{\circ} \mathrm{C}^{89}\right)$; ${ }^{1} \mathrm{H}$ NMR $\delta 0.73(\mathrm{~s}$, $3 \mathrm{H}), 0.84(\mathrm{~d}, 3 \mathrm{H}, J=6.6 \mathrm{~Hz}), 0.95(\mathrm{~s}, 3 \mathrm{H}), 0.96(\mathrm{~d}, 3 \mathrm{H}, J=6.7 \mathrm{~Hz}), 1.91(\mathrm{~s}, 3 \mathrm{H}), 3.44(\mathrm{~m}, 1 \mathrm{H})$, $4.53(\mathrm{q}, 1 \mathrm{H}, J=7.2 \mathrm{~Hz}), 5.27(\mathrm{~d}, 1 \mathrm{H}, J=4.4 \mathrm{~Hz}), 5.87(\mathrm{t}, 1 \mathrm{H}, J=5.9 \mathrm{~Hz}, \mathrm{NH}) ;{ }^{13} \mathrm{C}$ NMR $\delta 15.54$ (q), 16.30 (q), 17.72 (q), 19.42 (q), 20.81 (t), 23.35 (q), 27.66 (t), 31.42 (d), 31.55 (t), 31.87 (t), $32.03(\mathrm{t}), 33.38(\mathrm{~d}), 35.68(\mathrm{t}), 36.63(\mathrm{~s}), 37.23(\mathrm{t}), 39.66(\mathrm{t}), 40.13(\mathrm{~d}), 40.60(\mathrm{~s}), 42.23(\mathrm{t}), 44.82$ (t), 50.03 (d), 56.42 (d), 62.57 (d), 71.60 (d), 81.29 (d), 110.43 (s), 121.27 (d), 140.88 (s), 170.54 (s). The NMR spectra were compared to literature data of comparable compounds ${ }^{91}$.

Method B. To a solution of $\mathbf{3 6}(249.5 \mathrm{mg}, 0.44 \mathrm{mmol})$ in dioxane $(10 \mathrm{ml})$ was added an aqueous solution of $\mathrm{K}_{2} \mathrm{CO}_{3}(6 \mathrm{ml}, 0.3 \mathrm{M})$. After heating for 3 hours at reflux temperature, an aqueous solution of $\mathrm{NaOH}(1.5 \mathrm{ml}, 2 \mathrm{M})$ was added and reflux was continued for 2 hours. After 16 hours at room temperature, the reaction mixture was concentrated in vacuo, dissolved in $\mathrm{CHCl}_{3} / \mathrm{H}_{2} \mathrm{O}$ 1/1 (50 ml), extracted three times with $\mathrm{CHCl}_{3}(25 \mathrm{ml})$, dried, and evaporated in vacuo to yield a yellow foam. Recrystallization from acetone/hexane gave 38 (190.4 mg, 76\%) as a white solid. The NMR data are identical to those obtained with method A.

\section{References}

1. AVEBE, Postbus 15, 9640 AA VEENDAM.

2. Friedman, M.; McDonald, G.; Haddon, W. F. J. Ag. Food Chem. 1993, 41, 1397.

3. Gaši, K. T. M. P.; Djurendic, E. A.; Colic, D. R.; Sakac, M. N.; Arcson, O. N.; Mejacevic, L. M.; Miljkovic, D. A. J. Serb. Chem. Soc. 1997, 62, 451.

4. Gaši, K. M.; Miljkovic, D. A. J. Serb. Chem. Soc. 1988, 53, 165.

5. Gunic, E.; Tabakovic, I.; Gaši, K. M.; Miljkovic, D.; Juranic, I. J. Org. Chem. 1994, 59, 1264.

6. Gasi, K. M. P.; Kolic, D. R.; Arcson, O. N.; Sakac, Z. O.; Djurendic, E. A.; Sakac, M. N.; Medic, L.; Miljkovic, D. A. Collect. Czech. Chem. Commun. 1996, 61, 1655.

7. Schramm, G.; Österreichische Stickstoffwerke A.-G.: Austrian, 1970, p 8.

8. Herr, M. E.; The Upjohn Company: US, 1956; $\mathrm{p} 7$.

9. van Rheenen, V. J. Chem. Soc. D 1969, 314. 
10. Fatiadi, A. J. Synthesis 1976, 2, 65.

11. Fatiadi, A. J. Synthesis 1976, 3, 133.

12. Misztal, S.; Marek, C. Synthesis 1985, 12, 1134.

13. Harris, C. E.; Chrisman, W.; Bickford, S. A.; Lee, L. Y.; Torreblanca, A. E.; Singaram, B. Tet. Lett. 1997, 38, 981.

14. Holysz, R. P.; The Upjohn Company: Bundesrepublik Deutschland, 1955; p 5.

15. Holysz, R. P.; The Upjohn Company: US, 1956; p 6.

16. Meystre, C.; Frey, H.; Neher, R.; Wettstein, A.; Miescher, K. Helv. Chim. Acta 1946, 29, 627.

17. Morzycki, J. W.; Wilczewska, A. Z. Tetrahedron 1996, 52, 14057.

18. Schreiber, K.; Horstmann, C. Chem. Ber. 1966, 99, 3183.

19. Brougham, P.; Cooper, M. S.; Cummerson, D. A.; Heany, H.; Thompson, N. Synthesis 1987, 11, 1015.

20. Kim, H.-S. K., In-Chul; Lee, Sang-Ok Tetrahedron 1997, 53, 8129.

21. Carlsen, P. H. J. K., Tsutomu; Martin, Victor S.; Sharpless, K. Barry J. Org. Chem. 1981, 46, 3936.

22. Stewart, J. J. "MOPAC manual. Sixth edition. A general molecular orbital package," Frank J. Seiler Res. Lab.,U.S. Air Force Acad., 1990.

23. Stewart, J. J. P. J. Comput. Chem. 1989, 10, 209.

24. Stewart, J. J. P. J. Comput. Chem. 1989, 10, 221.

25. Beisler, J. A.; Sato, Y. Chemical Communications 1968, 16, 963.

26. Schramm, G.; Riedl, H.; Lentia G.m.b.H.: Germany, 1971; p 16.

27. Clarke, R. L.; Mooradian, A.; Lucas, P.; Slauson, T. J. Am. Chem. Soc. 1949, 71, 2821.

28. Staedel, W. Chem. Ber. 1886, 19, 1947.

29. Bai, D. X., Rui; Chu, Guohua; Zhu, Xingzu J. Org. Chem. 1996, 61, 4600.

30. August, R. A. K., Jeffrey A.; Moody, Claire M.; Young, Douglas W. J. Chem. Soc., Perkin I 1996, 6, 507.

31. Hobson, J. D.; McCluskey, J. G. J. Chem. Soc. 1967, 2015.

32. Hanaoka, M. K., Nobuyuki; Shimada, Ken-ichi; Mukai, Chisato J. Chem. Soc., Perkin I 1987, 677.

33. Hanaoka, M.; Nagami, K.; Imanishi, T. Heterocycles 1979, 12, 497.

34. Hanaoka, M.; Nagami, K.; Imanishi, T. Chem. Pharm. Bull. 1979, 27, 1947.

35. Zhang, C.; Gyermek, L.; Trudell, M. L. Tet. Lett. 1997, 38, 5619.

36. Olofson, R. A.; Abbott, D. E. J. Org. Chem. 1984, 49, 2795.

37. Dietzsch, K. Chem. Chem. Zeit. 1965, 27, 34.

38. Wentland, M. P. K., Rudolph K.; Tham, Fook S. J. Org. Chem. 1991, 56, 4701.

39. Ouannes, C.; Thal, C. Tet. Lett. 1981, 22, 951.

40. Kaminski, Z. J. P., P.; Rudzinski, J. J. Org. Chem. 1998, 63, 4248. 
41. Kunishima, M.; Kawachi, C.; Morita, J.; Terao, K.; Iwasaki, F.; Tani, S. Tetrahedron 1999, $55,13159$.

42. Kunishima, M. K., Chiho; Iwasaki, Fumiaki; Terao, Keiji; Tani, Shohei Tet. Lett. 1999, 40, 5327.

43. Rönsch, H. Zeit. fur Chem. 1979, 19, 447.

44. Marion, L.; Lemay, L.; Portelance, V. J. Org. Chem. 1950, 15, 216.

45. Morelli, J.-F.; Pouilhes, A.; Langlois, Y. Tetrahedron 1997, 53, 5195.

46. Smith, S.; Elango, V.; Shamma, M. J. Org. Chem. 1984, 49, 581.

47. Doshi, H.; Cardis, A. B.; Crelling, J. K.; Miller, S. I.; Dalton, D. R.; Zacharias, D. E.; Glusker, J. P. J. Org. Chem. 1987, 52, 2604.

48. Blasko, G.; Elango, V.; Sener, B.; Freyer, A. J.; Shamma, M. J. Org. Chem. 1982, 47, 880.

49. Cospito, G. C.; Illuminati, G.; Lillocci, C.; Petride, H. J. Org. Chem. 1981, 46, 2944.

50. Shamma, M.; Rothenberg, A. S.; Jayatilake, G. S.; Hussain, S. F. Tetrahedron 1978, 34, 635.

51. Maitra, U.; Breslow, R. Tet. Lett. 1986, 27, 3087.

52. Schramm, G.; Österreichische Stickstoffwercke A-G.: Austria, 1971, p 8.

53. Schreiber, K.; Adam, G. Experientia 1961, 17, 13.

54. Schreiber, K.; Adam, G. Liebigs Ann. Chem. 1963, 666, 176.

55. Schreiber, K.; Roensch, H. Tetrahedron Lett. 1963, 34, 329.

56. Schreiber, K.; Rönsch, H. Liebigs Ann. Chem. 1965, 681, 196.

57. Quyen, L. T.; Ripperger, H.; Adam, G.; Schreiber, K. Liebigs Ann. Chem. 1993, 167.

58. Schreiber, K.; Adam, G. Tetrahedron 1964, 20, 1707.

59. Bakker, C. C.; Vrijhof, P. Tetrahdron Lett. 1978, 19, 4699.

60. A-G, Ö. S.; Österreichische Stickstoffwerke A-G.: Republique Francais, 1970; p 16.

61. Gunda, T. E. Liebigs Ann. Chem. 1990, 311.

62. Brown, E. J. Austral. J. Chem. 1985, 38, 765.

63. A possible alternative for a shorter route from 28 to DPA (6) could have been the degradation via irradiation of a halogenated pregnane derivate, but the presence of the ?5,6 bond is prohibitive for this approach.

64. Quyen, L. T.; Ripperger, H.; Schreiber, K. Liebigs Ann. Chem. 1990, 519.

65. Quyen, L. T.; Ripperger, H.; Schreiber, K. Liebigs Ann. Chem. 1991, 143.

66. Kusano, G.; Aimi, N.; Sato, Y. J. Org. Chem. 1970, 35, 2624.

67. Vona, M. L. D.; Luchetti, L.; Rosnati, V. Tetrahedron 1994, 50, 8203.

68. Li, W.-R.; Hsu, N.-M.; Chou, H.-H.; Lin, S. T.; Lin, Y.-S. Chem. Commun. 2000, 5, 401.

69. Chiou, C.-M.; Kang, J.-J.; Lee, S.-S. J. Nat. Prod. 1998, 61, 46.

70. Krishnamurthi, K.; Vijayan, B.; Ramarajan, K. J. Indian Chem. Soc. 1992, 69, 373.

71. Cardona, L.; Garcia, B.; Pedro, J. R.; Ruiz, D. Tetrahedron 1994, 50, 5527.

72. Fischer, G.; Fritz, H.; Rihs, G.; Hunkler, D.; Exner, K.; Knothe, L.; Prinzbach, H. Eur. J. Org. Chem. 2000, 743. 
73. Czombos, J.; Aelterman, W.; Tkachev, A.; Martins, J. C.; Tourwe, D.; Peter, A.; Toth, G.; Fulop, F.; Kimpe de, N. J. Org. Chem. 2000, 65, 5469.

74. Wright, J. M.; Jones, G. B. Tetrahedron Lett. 1999, 40, 7605.

75. Wenglovsky, S.; Hegedus, L. S. J. Am. Chem. Soc. 1998, 120, 12468.

76. Kochetkov, N. K.; Torgov, V. I.; Malysheva, N. N.; Shashkov, A. S.; Klimov, E. M. Tetrahedron 1980, 36, 1227.

77. Pihko, P. M. K., Ari M. P. J. Org. Chem. 1998, 63, 92.

78. Adam, G.; Voigt, D.; Schreiber, K. Tetrahedron 1971, 27, 2181.

79. Wiesner, K.; Armstrong, R.; Bartlett, M. F.; Edwards, J. A. J. Am. Chem. Soc. 1954, 76, 6068.

80. Adam, G.; Huong, H. T. Tet. Lett. 1980, 21, 1931.

81. Attenburrow, J.; Cameron, A. F. B.; Chapman, J. H.; Evans, R. M.; Hems, B. A.; Jansen, A. B. A.; Walker, T. J. Chem. Soc. 1952, 1094.

82. Adam, G.; Schreiber, K. Tetrahedron 1966, 22, 3581.

83. Aoyama, T.; Sonoda, N.; Yamauchi, M.; Toriyama, K.; Anzai, M.; Ando, A.; Shiori, T. Synlett 1998, 2, 212.

84. Hohne, E.; Seidel, I.; Reck, G.; Ripperger, H.; Schreiber, K. Tetrahedron 1973, $29,3065$.

85. Sato, Y.; Latham, G.; Mossetig, E. J. Org. Chem. 1957, 22, 1496.

86. Sato, Y.; Ikekawa, N.; Mossetig, E. J. Org. Chem. 1960, 25, 783.

87. Engel, C. R.; Lachance, P.; Capitaine, J.; Zee, J.; Mukherjee, D.; Merand, Y. J. Org. Chem. 1983, 48, 1954.

88. Rousselet, G.; Capdevielle, P.; Maumy, M. L. Tet. Lett. 1995, 36, 4999.

89. Sato, Y.; Ikekawa, N. J. Org. Chem. 1960, 25, 786.

90. Bird, G. J.; Collins, D. J.; Eastwood, F. W.; Swan, J. M. Austral. J. Chem. 1979, 32, 597.

91. Cambie, R. C.; Potter, G. J.; Read, R. W.; Rutledge, P. S.; Woodgate, P. D. Austral. J. Chem. 1981, 34, 599.

92. Lawson, D. R.; Green, T. P.; Haynes, L. W.; Miller, A. R. J. Ag. Food Chem. 1997, 45, 4122.

93. Bird, G. J.; Collins, D. J.; Eastwood, F. W.; Exner, R. H.; Romanelli, M. L.; Small, D. D. Austral. J. Chem. 1979, 32, 783.

94. Schöpf, H.; Herrmann, R. Chem. Ber. 1933, 66, 298.

95. Beisler, J. A.; Sato, Y. J. Chem. Soc. 1971, 149.

96. Kraus, G. A.; Landgrebe, K. Tetrahedon Lett. 1984, 25, 3939.

97. Kadota, S.; Chen, A. Z.; Li, J. X.; Xu, G. J.; Namba, T. Phytochemistry 1995, 38, 777.

98. Vassova, A.; Voticky, Z.; Tomko, J. Coll. Czech. Chem. Comm. 1977, 42, 3643.

99. Kaneko, K.; Nakaoka, U.; Tanaka, M. W.; Yoshida, N.; Mitsuhashi, H. Tet. Lett. 1978, 24, 2099.

100. Bird, G. J.; Collins, D. J.; Eastwood, F. W.; Exner, R. H. Austral. J. Chem. 1979, 32, 797.

101. Ripperger, H.; Porzel, A. Phytochemistry 1992, 31, 1837. 
102. Qian, Z. Z.; Nohara, T. Phytochemistry 1995, 40, 979.

103. Schreiber, K.; Roensch, H. Liebigs Ann. Chem. 1965, 681, 187.

104. Wanyonyi, A. W.; Chhabra, S. C.; Mkoji, G.; Eilert, U.; Njue, W. M. Phytochemistry 2002, $59,79$.

105. Szendi, Z.; Forgo, P.; Sweet, F. Steroids 1995, 60, 442. 